OPEN ACCESS

Edited by:

Wouter Van Der Wijngaart Royal Institute of Technology, Sweden

Reviewed by: Agustin Leobardo Herrera-May, University of Veracruz, Mexico Wen Li,

Michigan State University, United States

*Correspondence:

Ferran Pujol-Vila

ferran.pujol@imb-cnm.csic.es Mar Alvarez

mar.alvarez@csic.es

Specialty section:

This article was submitted to Micro- and Nanoelectromechanical Systems,

a section of the journa Frontiers in Mechanical Engineering

Received: 19 March 2020 Accepted: 27 May 2020

Published: 28 July 2020

Citation: Pujol-Vila F, Villa R and Alvarez M (2020) Nanomechanical Sensors as a Tool for Bacteria Detection and Antibiotic Susceptibility Testing. Front. Mech. Eng. 6:44. doi: 10.3389/fmech.2020.00044

\section{Nanomechanical Sensors as a Tool for Bacteria Detection and Antibiotic Susceptibility Testing}

\author{
Ferran Pujol-Vila ${ }^{1 *}$, Rosa Villa ${ }^{1,2}$ and Mar Alvarez ${ }^{1 *}$ \\ ${ }^{1}$ Instituto de Microeletronica de Barcelona (IMB-CNM, CSIC), Campus UAB, Barcelona, Spain, ${ }^{2}$ CIBER de Bioengineria, \\ Biomateriales y Nanomedicina (CIBER-BBN), Barcelona, Spain
}

Nanomechanical biosensors refer to a subfamily of micro-electromechanical systems (MEMS) consisting of movable suspended microstructures able to convert biological processes into measurable mechanical motion. Owing to this, nanomechanical biosensors have become a promising technology in the way to detect and manage bacterial pathogens with improved effectiveness. The precise treatment of an infection relies on its early diagnosis; however, the current standard culture-based methods for bacteria detection and antibiotic susceptibility testing involve long protocols and are labor intensive. Thanks to its high sensitivity, fast response, and high throughput capability, nanomechanical technology holds great potential for overcoming some of the limitations of conventional methods. This review aims to provide a perspective on the diverse transducer structures, working principles, and detection strategies of nanomechanical sensors for bacteria detection and antibiotic susceptibility testing. Their performance in terms of sensitivity and operation time is compared with standard methods currently used in clinical microbiology laboratories. In addition, commercial systems already developed and challenges in the way of reaching real sensing application beyond the research environment are discussed.

Keywords: nanomechanical, microcantilever, mems, bacteria, antibiotic, biosensor

\section{INTRODUCTION}

In the last years, micro- and nanotechnologies have gained interest and been positioned in the forefront in the fight against bacterial pathogens. Recent developments include nanomechanical sensors, CMOS sensors, photonic crystals, and wearable sensors, which hold great promise in improving the main drawbacks of conventional methods (Mannoor et al., 2012; Nikkhoo et al., 2016; Yen and Chiu, 2020). Several recent publications review the current advances in analytical and emerging technologies for bacteria identification and antibiotic susceptibility testing (AST) (Longo and Kasas, 2014; Li et al., 2017; Syal et al., 2017a; Leonard et al., 2018; Behera et al., 2019; Shin et al., 2019). Among the emerging technologies, nanomechanical sensors have aroused great interest due to their high integration, multiplexing capability, outstanding sensitivity, and fast response with respect to other technologies (Mutharasan, 2008; Ahmed et al., 2014). In this review, we intend to provide an in-depth overview of nanomechanical sensors applied to bacteria detection and AST.

Nanomechanical sensors are able to convert biological interactions and processes occurring at their surface into measurable mechanical motion. Nanomechanical sensors have emerged as 
highly sensitive and versatile tools for label-free biosensing in real time (Arlett et al., 2011). These sensors evolved from the probes used in Atomic Force Microscopy (AFM) and reach today unprecedented performances (e.g., sensitivity, time response, or integration) thanks to the advances in microand nanofabrication technologies. Since the first microcantilever biosensor based on DNA hybridization and antigen-antibody binding was reported in 2000 (Fritz, 2000), many researchers have stressed this concept using a variety of suspended mechanical structures for the quantification of a plethora of analytes, e.g., DNA, proteins, viruses, and cells. Sensitivity ranges in the order of picomolar concentration, attogram, and single-cell levels highlight the excellent sensitivity of these systems (Alvarez and Lechuga, 2010; Arlett et al., 2011; Tamayo et al., 2013).

Due to this high sensitivity, joined to their integration and array configuration capability (Fritz, 2008), nanomechanical systems represent a very promising technology in the race to detect and manage bacterial pathogens with improved efficiency. Infectious diseases caused by bacterial pathogens are still considered one of the biggest threats to global health in the current era in resource-limited areas and also in developed countries (Bloom and Cadarette, 2019). Drugresistant bacteria cause 700,000 deaths annually worldwide, and experts predict the number could grow to 10 million by 2050 due to the emergence of antibiotic resistance (Aslam et al., 2018). In this regard, bacteria detection and AST technologies play a crucial role in diagnosis as well as in the rational design of antimicrobial therapies (Okeke et al., 2011). The precise treatment of an infection relies on its early diagnosis; however, the current standard culture-based methods for bacteria detection involve long protocols and demand skilled personnel, and culture-independent approaches use complex and expensive instrumentation. On the other hand, conventional AST methods used in clinical practice (e.g., broth microdilution or the disk diffusion method) are accurate but labor intensive and timeconsuming (16-24h to obtain a result). These operational limitations generate a wide gap (days) between sample processing from patients and final results, which delay the initiation of precise targeted antimicrobial therapy while extending the administration of broad-spectrum antibiotics (Puttaswamy et al., 2018). In addition, the prolonged use of broad-spectrum antibiotics increases the chances for development of antibiotic resistance among microbial communities. Rapid and affordable AST is expected to accelerate the initiation of targeted antibiotic therapy, thus improving clinical outcomes. Furthermore, this technology envisages a more accurate use of broad-spectrum antibiotics as a way to decrease the emergence of antimicrobial resistance among bacteria (Leonard et al., 2018). For these reasons, the development of new rapid and sensitive technologies for bacteria detection and AST is of high priority in the way to tackle infectious diseases and reduce the antibiotic resistance risk (Dinarelli et al., 2017).

Recent advances in nanomechanical sensors offer a high potential to overcome the limitations of conventional methods for bacteria detection and AST. In this review, a perspective of the diverse transducer structures employed in bacterial sensing is provided with a focus on dimensions, shape, and readout schemes. The main working principles (dynamic and static) and detection strategies are reviewed in detail, including the biochemical functionalization of the sensors. Nanomechanical sensor performance, in terms of sensitivity and operation time, is compared with standard methods. Commercial systems already developed and future challenges of this technology in the way to reach the clinical practice are discussed.

\section{NANOMECHANICAL TRANSDUCERS AND DETECTION SCHEMES}

The sensitivity of nanomechanical sensors for the detection of biochemical agents in general and bacteria in particular depends on the combination of several factors, such as shape, dimensions, materials, operation mode, detection scheme, surrounding medium, and functional layer, which must be weighted depending on the final application. In order to narrow the topic, the following subsections have been described, trying to focus as far as possible on applications for bacteria sensing.

\section{Detection Schemes}

The detection of pathogens (including their growth or metabolic activity) occurs at the sensor surface, inducing a deformation of the sensor (static response) or/and a change in their resonance frequencies (dynamic response) as shown in Figure 1. Both operation schemes have been widely used for the sensing of bacteria.

In the dynamic mode, the cantilever is driven at its resonance frequency by thermal and ambient noise (Brownian motion) or by piezoelectric or magnetic actuators. When bacteria attach to the cantilever surface, the resonance frequency shifts as a function of the added mass load and the position on the sensor. In this mode, the cantilevers behave like a harmonic oscillator, and the performance depends mainly on their resonance frequency, $f$-determined by the cantilever spring constant, $\mathrm{k}$, and effective mass, $\mathrm{m}$-and their quality factor, $\mathrm{Q}$, which depends on the surrounding medium (Johnson and Mutharasan, 2012):

$$
f=\frac{1}{2 \pi} \sqrt{\frac{k}{m}}
$$

Nanomechanical transducers operating in dynamic mode are able to weigh the biomass of attached cells with high sensitivity, achieving single-cell (typical bacterial cell weight $\sim 1$ picogram) or even femtogram resolution (Burg et al., 2007). In addition, increases of biomass load associated with cell growth can be monitored as an indicator of the bacterial growth rate (Gfeller et al., 2005a).

The performance of dynamic-mode cantilevers is severely affected by damping in liquid medium due to viscosity (which reduces the $\mathrm{Q}$ factor). Considering that aqueous solution is the physiological environment of living cells, different strategies have been explored to circumvent this limitation. A typical approach consists in collecting cells in liquid and performing measurements in air or vacuum. Other approaches achieve a high mass sensitivity in liquid medium by reducing the resonator size to the nanoscale (increasing its resonance frequency), amplifying 


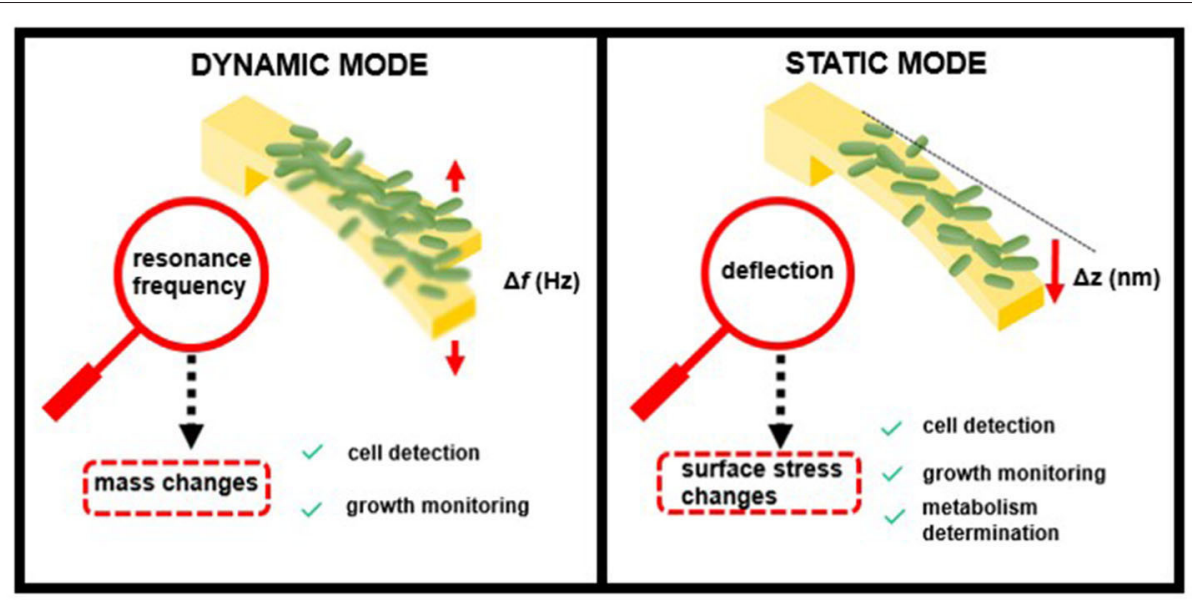

FIGURE 1 | Modes of operation of nanomechanical sensors in bacterial biosensing.

the resonator movement (increasing the quality factor) by using internal or external excitation sources (Johnson and Mutharasan, 2012), or working in higher resonance modes (Jin et al., 2006; Hajjaj et al., 2020). Instead of reducing the resonator size, several works exploit the use of large piezoelectric cantilevers (millimeter-sized) under flow conditions without significant loss of Q value (Campbell and Mutharasan, 2006b). In contrast to micro- or nano-meter resonators, millimeter-sized cantilevers present a high Reynold number, causing a hydrodynamics behavior dominated by inertial forces (Mutharasan, 2008). In a recent publication, the relation between $\mathrm{Q}$ and the signalto-noise ratio (SNR) is reanalyzed, finding that the frequency stability of resonant nanomechanical sensors can be improved by lowering the quality factor (Roy et al., 2018). The authors confirm that $\mathrm{Q}$ and SNR behave inversely for intrinsically limited resonators and find stability improved with damping, which open the door to high-performance ultrasensitive resonators in liquid environments. An alternative attractive strategy is the use of cantilevers with integrated microfluidic channels within the mechanical structure, which allows making measurements in a vacuum under liquid flow conditions (Burg and Manalis, 2003).

When operating in static mode, the transducer deflection derives from a change in surface stress induced by any event, e.g., adsorption or biorecognition, which takes place on only one side of the sensor. Forces playing a role during this event and inducing a change in the surface stress include electrostatic, steric interactions, hydration, or entropy (Mathew and Ravi Sankar, 2018). The resulting surface stress can be compressive or tensile, depending on the surface energy. The relation between the surface stress change, $\Delta \sigma$, and the resulting cantilever bending, $\Delta z$, is usually described using Stoney's equation (Stoney, 1909):

$$
\Delta \sigma=\frac{E t^{2}}{3(1-v) L^{2}} \Delta z
$$

where $E$ is the Young's modulus, $v$ is the Poisson coefficient, and $L$ and $t$ are the cantilever length and thickness, respectively. The resulting cantilever bending and, therefore, the cantilever sensitivity to detect surface stress changes depends on the cantilever material and dimensions.

Cell binding to one of the cantilever surfaces causes deflection by changes in surface stress, thus allowing determination of the presence or concentration of specific bacterial strains. Although being less sensitive than the dynamic mode of operation, this detection principle is highly versatile because it is able to detect many different factors that cause changes in surface stress and is not affected by liquid damping (Alvarez and Lechuga, 2010). Bimaterial cantilevers, which are coated on one side with a thin metal layer (often gold), can provide improved sensitivity in bacterial biosensing based on static measurements. The asymmetric nature of these hybrid cantilevers enhances their response to surface stress, taking advantage of the differing material properties, such as Young's modulus, conductivity, and thermal expansion (Singamaneni et al., 2008).

\section{Readout Techniques}

Mechanical responses can range from angstroms to hundreds of nanometers, requiring extremely sensitive (and complex) readout techniques for accurate quantification of the movement. Among the most popular readout schemes are optical beam deflection, piezoelectric, and piezoresistive. Optical detection is the most widespread technique because it is simple to implement for a single transducer and provides sub-angstrom resolution. This scheme is based on a laser beam reflected at the cantilever free-end. A two-quadrant photodetector or a position-sensitive photodetector measures the displacement of the reflected beam due to the cantilever movement (Hansen and Thundat, 2005). The resonance frequency is usually measured by performing an FFT of the signal and fitting the obtained peak to an oscillator model to obtain the resonance frequency and Q factor. Static measurements may involve the subtraction of a reference signal. As disadvantages, the optical beam detection method involves an alignment of the elements and a recalibration of the system; it is difficult to implement in an array configuration, and it is affected by the transparency of the medium. On the 
other hand, electrical detection is performed by integration of piezoelectric or piezoresistive materials in the cantilever, which is advantageous when working with arrays of transducers. Piezoelectric cantilevers are susceptible to be self-excited by electric actuation, which enhances their analytical capacity when working in the dynamic mode. Piezoresistive sensing is based on the resistance change of a conductor when strained and typically uses a Wheatstone bridge (WSB) configuration to reduce cross-talk and improve SNR. The WSB converts the resistance change into a voltage signal equivalent to the net induced surface stress. Piezoresistive readout also offers flexibility for on- or off-chip signal processing circuitry and compatibility with integrated circuit (IC) and CMOS fabrication processes. One of the drawbacks of this approach is its intrinsically larger electrical noise than the optical method (Bausells, 2015). Capacitive detection has gained attention in the last years for the detection of the deflection produced in membranes, where the integrated capacitor plates are isolated from the electrolyte solution that could cause faradaic currents (Tsouti et al., 2011; Jian et al., 2017).

\section{Dimensions, Shape, and Fabrication Techniques}

Nanomechanical transducers with different geometries, sizes, and clamping configurations have been used in bacterial sensing according to the detection purpose. Microcantilevers are the most common mechanical structures with dimensions typically hundreds of $\mu \mathrm{m}$ long, tens of $\mu \mathrm{m}$ wide, and about $0.3-1 \mu \mathrm{m}$ thick. In general, thinner and longer suspended structures and materials with low Young's modulus (low stiffness) are preferred for working on the static mode although the opposite (stiffer structures with high frequency and high Q) is recommended for working under the dynamic mode as follows from Equations (1) and (2). At the same time, microcantilever shape is preferred instead to membrane shape when combined with the optical beam detection technique, offering, in general, higher sensitivities than the electrical readings of piezoresistive microcantilevers due to the intrinsic electrical noise.

Microcantilevers are mainly fabricated by silicon technology (silicon, silicon nitride, or silicon oxide) with rectangular or V-shape as typical geometries (Carrascosa et al., 2006; Waggoner and Craighead, 2007). Silicon-suspended structures are fabricated by bulk or surface micromachining processes. Both processes are based in the transfer of the pattern by photolithography followed by an etching to define the 3-D structures. Bulk micromachining selectively etches the silicon substrate to create the microstructures, classically by using wet etching techniques, while surface micromachining uses the deposition of a sacrificial layer followed by a device layer, and a dry etching of the sacrificial layer (Waggoner and Craighead, 2007). Piezoelectric and piezoresistive mechanical transducers are fabricated by adding different steps to the standard silicon microfabrication processes for the deposition and etching of the different materials (piezoresistor, piezoelectric, metals, etc.) (Alava et al., 2010; Bausells, 2015). The reduced complexity of the fabrication process of the standard microcantilever with respect to the piezoelectric or piezoresistive one, together with the high sensitivity and easy implementation of the optical beam detection system, converts this configuration to the most extended one for biosensing in general and for detection of bacteria and AST in particular. Other technologies, such as electron beam lithography (EBL) and focused ion beam (FIB), allow the fabrication of suspended structures on the nanoscale and the controlled deposition of mass into the transducers (Sage et al., 2018; Gruber et al., 2019). Great efforts have also been made in the use of microfabrication technologies compatible with CMOS fabrication processes to increase miniaturization and integration with the signal processing electronics (Verd et al., 2008; Qu and Xie, 2012; Maruyama et al., 2018; Yen and Chiu, 2020).

Although mostly silicon-based microcantilevers have been used as nanomechanical biosensors, polymeric suspended structures have also been manufactured and applied for the sensing of bacterial pathogens. Fabrication of polymeric suspended structures usually includes steps such as spin coating, deposition, photolithography, and etching (Bridle et al., 2016; Mathew and Ravi Sankar, 2018). Polymeric and hydrogel microcantilevers have also been fabricated by injection molding (Urwyler et al., 2011), which is a fast and cost-effective microfabrication technique for replicating soft materials using a solid microscale mold as a template, and by dynamic mask lithography (Yoon et al., 2019), respectively. Alternative fabrication methodologies, such as 3-D printing, have been explored as a convenient way to reduce the use of expensive equipment at specialized clean-room facilities and save time to obtain a final device for fast testing and evaluation (Stassi et al., 2017). So far, these last techniques have not been applied to the sensing of bacteria.

Nanomechanical structures, such as micromembranes, based in silicon or polymer technology can range in the hundreds of $\mu \mathrm{m}$ diameter and around $1 \mu \mathrm{m}$ thickness (Yoshikawa et al., 2011; Chatzipetrou et al., 2013). The detection of the bending response of clamped membranes usually requires the use of optical techniques with higher sensitivities (i.e., interferometry) due to the movement constraints imposed by the clamping edges. Membrane-type suspended structures with demonstrated sensitivity to the presence of living cells include peripherally clamped membranes (Sang and Witte, 2010) and pedestal structures (suspended on four beams) (Park et al., 2010), measured by optical interferometry and a laser Doppler vibrometer, respectively. In contrast, piezoresistive doubleclamped beams and membranes supported by two or four sensing beams demonstrate higher sensitivities than their counterpart piezoresistive microcantilevers, reaching sensitivities comparable to the optical bending technique (Yoshikawa et al., 2011; Loizeau et al., 2015; Yen and Chiu, 2020) although these configurations have not been applied to the sensing of bacteria.

\section{Functional Coatings}

As in any kind of biosensor, the mechanical transducer must be coated with a biorecognition element (i.e., proteins, nucleic acids, carbohydrates, etc.) specific to the analyte to be detected. The quality and specificity of this receptor layer affect the 
final sensitivity of the system. Parameters, such as surface roughness, surface coverage, homogeneity, and reproducibility, have a direct effect on the mechanical transduction in both the static and dynamic operation modes. Several works have demonstrated the effect of surface inhomogeneity and location of the element on the mechanical response of microcantilevers and membranes (Ramos et al., 2007a,b; Tsouti and Chatzandroulis, 2012, 2015; Kim et al., 2015; Minami and Yoshikawa, 2020). Cells or bacteria detected at the microcantilever free-end increase the microcantilever mass, reducing its resonance frequency, while cells close to the clamping region have a larger effect on the resonator spring constant, increasing its resonance (Ramos et al., 2007a; Imamura et al., 2016). In contrast, membranetype structures are less affected by the quality of the coatings, which result in a higher stability of the signal (Loizeau et al., 2015). In a very interesting work, Patil et al. hypothesize the effect of the chemistry and geometry of the sensing layer in the signal sensitivity, demonstrating that capture molecules arranged parallel to the long axis of a microcantilever produce a larger surface stress response than those arranged in the transverse configuration (Patil et al., 2018).

Biochemical coatings are sensitive to the method used, which, at the same time, are constrained by the functionalization requirements for working in the static or dynamic modes. The detection of surface stress changes is restricted to the functionalization of a single side of the sensor, making necessary the use of techniques that allow the functionalization of suspended small areas. Some of the used techniques include inkjet printing or the use of a single side metal coating combined with selective metal or silicon chemistry (i.e., thiols and silanes) (Álvarez et al., 2004; Bietsch et al., 2004; Etayash et al., 2015).

\section{BACTERIA DETECTION}

\section{Resonance Mode}

Bacteria detection has been demonstrated by using both static and dynamic operation modes. In a pioneering work, Llic et al. reported the immunospecific detection and quantification of enterrohemorrhagic Escherichia coli (E. coli) O157:H7 (Ilic et al., 2000), a serotype that causes outbreaks of bloody diarrhea and hemolytic uremic syndrome (Nguyen and Sperandio, 2012), using nanomechanical sensors working in dynamic mode excited by thermal and ambient noise. Binding of the Gram-negative bacterium to antibody-coated silicon nitride microcantilevers induced a shift in the measured resonant frequency correlated to the mass of the bound E. coli O157:H7 cells, achieving a detection limit of 16 cells in $<20 \mathrm{~min}$ (which corresponds to a mass of $6 \mathrm{pg}$ ). Since then, many works have exploited this concept, showing that the presence and concentration of specific bacterial species/strains can be quickly measured with dynamicmode nanomechanical sensors. The bacteria adsorption can have opposite effects on the resonance frequency depending on the position and extent of the bacteria (Ramos et al., 2007b). In general, the detection selectivity is addressed by chemical functionalization of the transducer surface with specific biorecognition molecules, often antibodies. Remarkably, single cell detection of E. coli O157:H7 was performed in air within a short time (Ilic et al., 2001). Based on a similar detection scheme, the Gram-positive bacterium Listeria innocua was quantitatively determined down to very low numbers (10 attached cells) (Gupta et al., 2004). More recently, a whole intact E. coli DH5 $\alpha$ bacteria was also detected and characterized (mass and stiffness) under a vacuum environment by using nanomechanical spectrometry (Malvar et al., 2016). In this work, a bacterium was delivered by electrospray ionization onto a silicon nitride microcantilever (Figure 2A), and the resonance frequencies of the first four flexural vibration modes of the cantilever were tracked. Authors applied an inverse problem algorithm to the quasi-instantaneous jumps produced on the eigenfrequencies as each bacterium lands on the microcantilever (Figure 2B) to obtain the mass ratio and stiffness factor of the bacterial particles for a total of 189 events. In a very recent publication, the same group demonstrates the optomechanical detection of the low-frequency vibration modes of a single bacterium (S. epidermidis) by using disk resonators with similar resonance frequency $(500 \mathrm{MHz})$ to the bacterium vibration (Gil-Santos et al., 2020).

Piezoelectric-excited lead zirconate titanate-stainless steel cantilevers with millimeter dimensions (PEMC) were tested for in situ detection of cells in water samples (Yi et al., 2003). Overcoming some of the limitations imposed by liquid damping, poly-L-lysine-coated cantilevers presented a resonance frequency response proportional to the concentration of the yeast Saccharomyces cerevisiae (S. cerevisiae), thus opening the possibility of real-time assessment of bacteria in aqueous media. This possibility was later demonstrated by means of identical PEMC by detection of the pathogenic E. coli O157:H7 in less than an hour at very low concentrations ( 1 cell $\mathrm{mL}^{-1}$ ) (Campbell and Mutharasan, 2005, 2007a). In addition, the performance of the millimeter-sized nanomechanical transducers in complex matrices and food samples was analyzed (Campbell et al., 2007b). Culture broth and culture broth plus raw ground beef samples supplemented with E. coli O157:H7 were successfully assessed, pointing out the suitability of this configuration for the analysis of real food samples. On the other hand, rapid immunodetection of the foodborne pathogen Listeria monocytogenes (L. monocytogenes) in milk samples, down to $10^{3}$ cells $\mathrm{mL}^{-1}$, was reported using similarly sized piezoelectric-excited cantilevers (Sharma and Mutharasan, 2013). Other relevant foodborne pathogens, i.e., Vibrio cholerae and Salmonella typhimurium, and warfare agents, i.e., Bacillus anthracis, were assessed similarly with good sensitivities using antibody-coated PEMC (Yi et al., 2003; Campbell and Mutharasan, 2006a; Sungkanak et al., 2010). In a first approach, Campbell and coworkers reported the use of PEMC coated with antibodies specific to the spores of Bacillus anthracis (B. anthracis), which causes anthrax disease and represents one of the main bioterrorism agents. The spores were selectively detected in liquid at a low concentration $\left(300\right.$ spores $\left.\mathrm{mL}^{-1}\right)$ in the presence of spores of Bacillus thuringiensis (Campbell and Mutharasan, 2006a). In addition, as few as 50 spores bound to cantilevers excited by thermal noise were detected in water (Davila et al., 2007). On the other hand, an integrated system composed of an air sampler and PEMC sensors achieved higher performance, showing response to 38 spores $\mathrm{L}^{-1}$ in near real time 

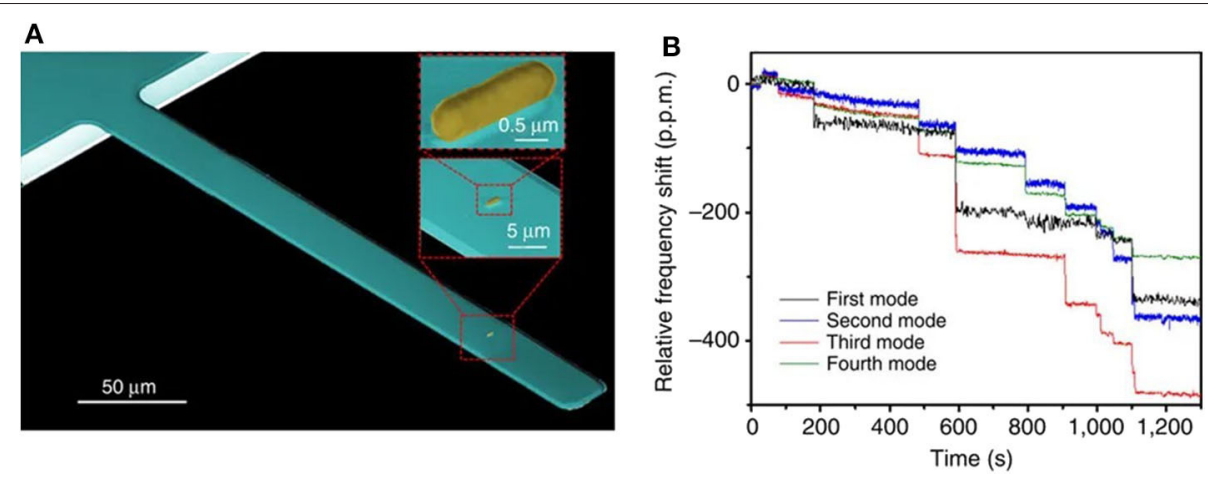

FIGURE 2 | Bacteria detection with dynamic mode nanomechanical sensors. (A) SEM image of a cantilever with an E. coli cell. (B) Real-time record of the fractional shifts of the resonance frequencies of the first four vibration modes of the microcantilever during bacteria adsorption. The time-correlated frequency jumps correspond to adsorption events of single bacterial cells. Reprinted from Malvar et al. (2016).

(Campbell et al., 2007a). Other works improved the selectivity of the detection of B. anthracis spores against other endosporeforming bacteria (Campbell and Mutharasan, 2007b; McGovern et al., 2008).

In order to enhance bacterial sampling and adhesion to the transducer in liquid samples, coupled electro-nanomechanical sensors were employed. A device that combined gold microelectrodes embedded onto the surface of a silicon cantilever was able to capture E. coli by electrokinetic effects (dielectrophoresis). Significant resonance frequency shifts (double) were found for poly-L-lysine-coated electrokinetic cantilevers in contrast with unassisted capture (after $30 \mathrm{~min}$ of collecting $10^{8}$ particles $/ \mathrm{mL}$ ) (Tomkins et al., 2013). Using a similar device integrating sandwich electrodes for piezoelectric actuation and electrokinetic collection, E. coli was detected within $10 \mathrm{~min}$ in stationary and flowing samples (Leahy and Lai, 2017b). The estimated sensitivity of the seventh resonant mode was $326 \mathrm{fg} / \mathrm{Hz}$ (for a flowing sample of $400 \mu \mathrm{l} / \mathrm{min}$ with a concentration of $10^{5}$ cells $/ \mathrm{ml}$ ). Exploiting as well the electrokinetic capture, bacterial detection in a micron-sized gap at the free end of a cantilever allowed real-time measurement of 100 cells $\mathrm{mL}^{-1}$ (Leahy and Lai, 2017a).

Alongside bacterial detection, dynamic-mode cantilevers enabled monitoring the bacterial growth too. Microcantilevers coated with common nutritive layers, e.g., agarose, were sensitive to cell proliferation, being able to detect active growth of E. coli cells within $1 \mathrm{~h}$ under temperature- and humidity-controlled conditions (Gfeller et al., 2005b). It was proposed that microbial growth promoted an increase of water absorption by the nutritive layer to compensate the water and nutrient uptake by the growing cells, inducing a shift in the microcantilever resonance frequency. The calculated mass sensitivity from the bacterial growth was $\sim 140 \mathrm{pg} / \mathrm{Hz}$, which theoretically would allow the detection of 200 E. coli cells. Growth of immobilized mycelial fungus Aspergillus niger and unicellular yeast $S$. cerevisiae led to resonance frequency shifts (in a range of $10^{3}-10^{6} \mathrm{CFU} \mathrm{ml} \mathrm{ml}^{-1}$ ) within a few hours, much faster than conventional culture techniques (Nugaeva et al., 2005).

Microfluidic cantilevers based on suspended silicon microchannel resonators (SMR) operating in a vacuum could weigh single E. coli and Bacillus subtilis (B. subtilis) cells with sub-femtogram resolution, thus improving the performance and analytical capabilities of nanomechanical sensors while maintaining the physiological conditions of the bacteria (Burg et al., 2007). Specifically, the measured masses of E. coli and B. subtilis were $\sim 110$ and $\sim 150 \mathrm{fg}$, respectively, using SMR. Later, the suspended microchannel resonator combined with picoliter-scale fluidic control was used to measure the buoyant mass of B. subtilis, E. coli, S. cerevisiae, and mouse lymphoblasts with femtogram precision allowing determination of their "instantaneous" growth rates (Godin et al., 2010). Finally, the device was adapted to achieve high-throughput capacity using serial microfluidic mass sensor array. By using an array of SMR fluidically connected in series and separated by "delay" channels, Cermak et al. measured the growth rates of several individual cells simultaneously (E. coli and Enterococcus faecalis) (Cermak et al., 2016).

Other transducer configurations operating in resonant mode have also been employed for bacterial biosensing purposes. Circular silicon membranes integrating a piezoelectric actuator and a boron-doped silicon piezoresistor as sensing elements were tested for the assessment of endospores of Bacillus atrophaeus, used as a non-pathogenic model of biological warfare agents (e.g., Bacillus anthracis). These membrane transducers allowed immunodetection of $10^{8}$ spores $\mathrm{mL}^{-1}$ in air and water (Alava et al., 2010). Park and coworkers developed an array of square pedestal resonant mass sensors to measure the biophysical properties of human colon adenocarcinoma cells (Park et al., 2010). Interestingly, the pedestal transducers had a positionindependent mass sensitivity being able to determine cell stiffness (Young modulus), mass, and growth rate of single attached cells, which could as well be useful for detection and characterization of microorganisms.

\section{Static Mode}

Nanomechanical sensors working in static mode have also demonstrated high sensitivity to cell adsorption and, therefore, a high potential for pathogen detection. Binding of low bacterial numbers on one cantilever side induces surface stress changes that cause the deflection of the cantilever, which allow the 
detection of the pathogenic bacteria. As a proof of concept, E. coli $\mathrm{O} 157: \mathrm{H} 7$ was quantitatively assessed in real time by using silicon nitride V-shaped microcantilevers, functionalized with antibodies, and a bending detection scheme based in the optical beam deflection method (Zhang and Ji, 2004). Using a similar detection scheme, Salmonella enterica (S. enterica) strains, a common foodborne pathogen responsible for zoonotic infections in humans and animals (Jajere, 2019), were detected. Remarkably, as low as 25 attached cells were detected within minutes of analysis in aqueous solution with good strain selectivity (Weeks et al., 2006).

Bimaterial cantilevers operating in static mode allowed highly selective detection thanks to functionalization with diverse bio-recognition molecules, such as carbohydrates and peptides. For instance, peptide-functionalized gold-coated silicon cantilevers presented good selectivity for B. subtilis spores (Dhayal et al., 2006). In addition, various E. coli strains were quickly (minutes) detected by means of gold-coated silicon cantilevers functionalized with self-assembled layers of glycans (trimannosides and non-amannosides) (Mader et al., 2012). As shown in Figure 3, three different E. coli strains were discriminated by differential deflection of the cantilever sensors. In the same way, Wang and coworkers reported an array of bimaterial (gold-silicon) microcantilevers coated with peptides derived from phage display libraries. Rapid and accurate quantification of Salmonella spp. was achieved, demonstrating its potential for detection as well as a screening method (Wang et al., 2014). More recently, a nucleic acid-based approach was explored for molecular recognition and sensitive detection of foodborne pathogens. Gold-coated silicon cantilevers were modified with diverse ssDNA molecules corresponding to specific nucleotide sequences of E. coli O157:H7, Vibrio parahaemolyticus, Salmonella, S. aureus, L. monocytogenes, and Shigella. The target ssDNA molecules were obtained from the microorganisms by genomic DNA extraction and denaturation and linked to gold nanoparticles as a way to amplify the sensor response. The microcantilever array sensor enabled simultaneous determination of the multiple bacteria at concentrations as low as 1-9 cells $\mathrm{mL}^{-1}$ with a working range of three orders of magnitude. Hence, this strategy represents a significant advance in DNA-based pathogen detection due to its ultrasensitive, fast, and high-throughput fashion (Zheng et al., 2019).
By increasing integration, three different detection techniques were combined in a single nanomechanical device for the detection of bacteria in real time and measurement of their susceptibility to antibiotics as shown in Figures 4A-E (Etayash et al., 2016). A gold-coated silicon nitride microcantilever containing an embedded microfluidic channel captured bacteria and measured changes in deflection (due to surface stress changes caused by cell binding) as shown in Figure 4F and changes in resonance frequency (due to cell mass) as shown in Figure 4G. In addition, the infrared (IR) spectra of trapped bacteria was measured by excitation with IR radiation that induced deflection of the cantilever proportional to the IR absorption of the cells, shown in Figure $\mathbf{4 H}$. This multidimensional analysis enabled in situ detection and identification of bacteria strains and accurate discrimination between injured and intact cells. A waterborne parasite (Cryptosporidium) was also detected by using microfluidic cantilevers fabricated in polyimide and working in static mode (Bridle et al., 2016).

Other approaches for bacterial detection in static mode include the use of different materials and mechanical structures. Elastomeric micro-membrane surface-stress sensors made of polydimethylsiloxane (PDMS) were used, taking advantage of their low stiffness (the Young's modulus of PDMS is three orders of magnitude smaller than that of silicon), which may enhance the mechanical response to surface stress. By using a fiber optic interferometer and a white light interferometer, gold-coated PDMS membranes functionalized with 11-mercaptoundecanoic acid (MUA) were applied to the detection of E. coli. Interestingly, the deflection caused by living bacteria was higher than in the case of dead bacteria, which may be derived from changes in the chemical composition of the cell surface after death (Sang and Witte, 2010). In a similar approach, capacitive surfacestress membrane biosensors functionalized with alkene-thiolate molecules distinguished between live and dead Staphylococcus aureus (S. aureus) with good sensitivity (Sang et al., 2015).

\section{Sensitivity Comparison With Standard Methods}

Table 1 summarizes the main features of the described works to facilitate the analysis of sensitivity and comparison between works. Silicon cantilever combined with optical beam detection is the most extended configuration for the detection of bacteria
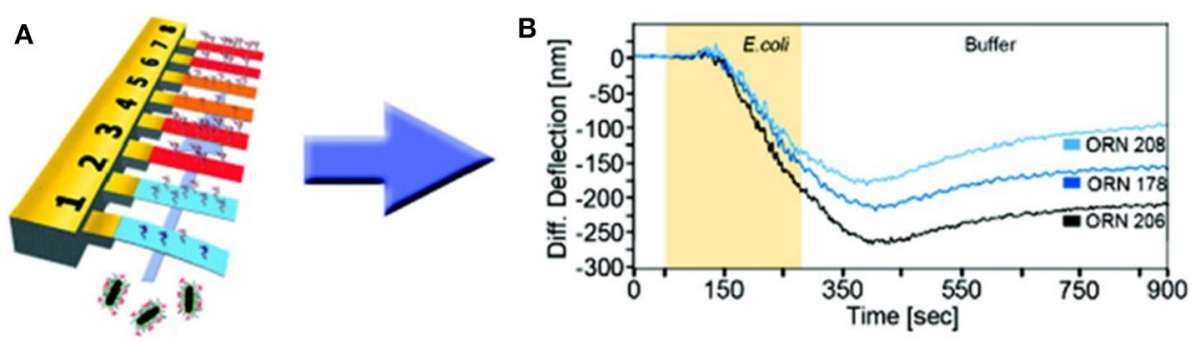

FIGURE 3 | Bacteria detection with static mode nanomechanical sensors. (A) Schematic representation of a gold-coated silicon cantilever array sensor functionalized with self-assembled monolayers of glycans. (B) Discrimination of three different $E$. coli strains by differential deflection of the cantilever sensors. Reprinted from Mader et al. (2012) with permission from the American Chemical Society. 


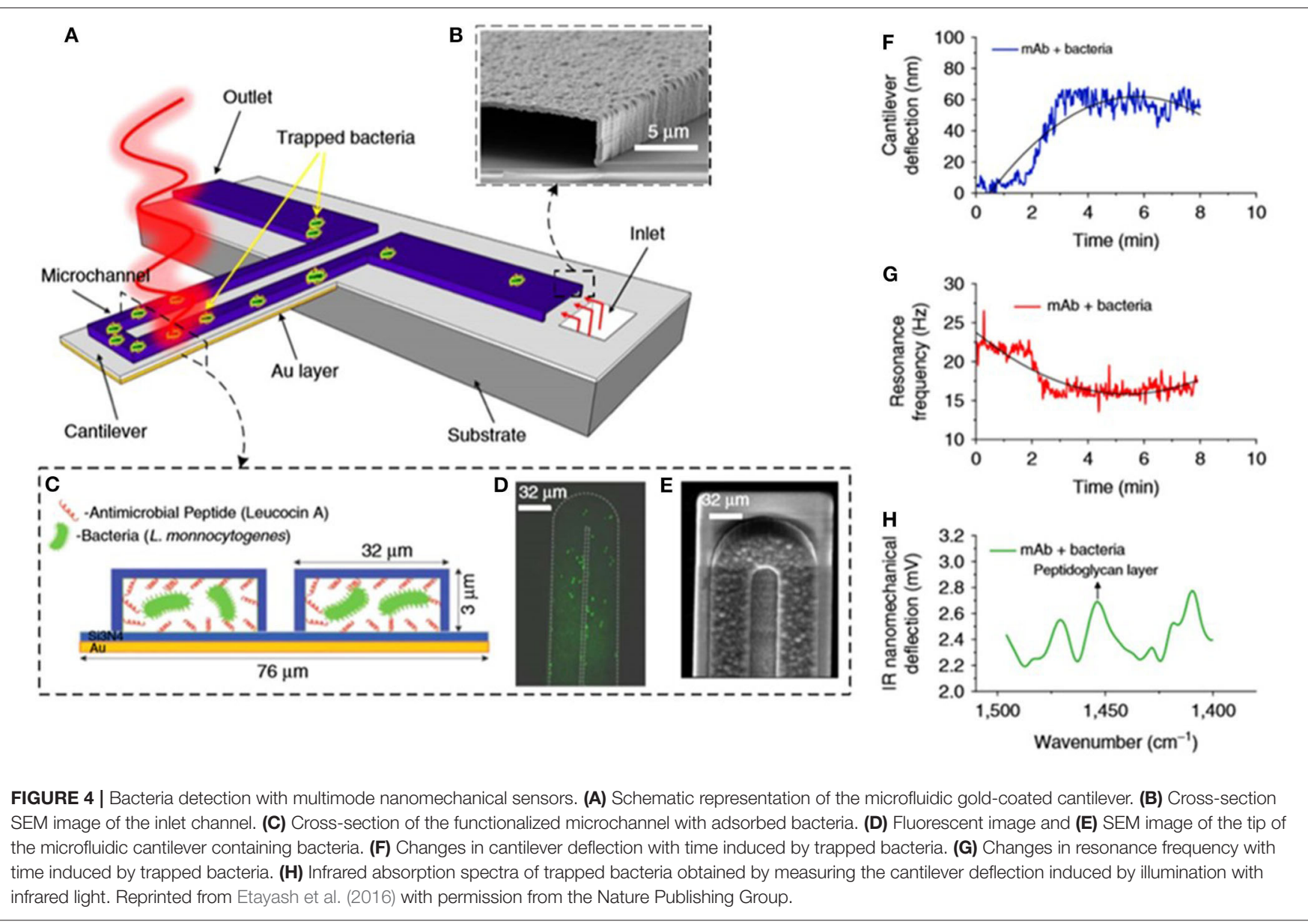

working in dynamic and static modes. Although it is true that the most recent publications also apply other configurations (i.e., suspended microchannel or membranes) and materials (i.e., polymers). Comparison of sensitivity is not easy because different concepts, such as sensitivity, limit of detection, or even number of cells measured in a single experiment, are used in the different works. Regardless of their mode of operation, either dynamic or static, attachment of a few cells (in most cases $<10^{3}$ ) onto nanomechanical transducers produces a measurable response. In general terms, dynamic-mode sensors yield higher detection limits than static ones (even down to the single cell regime), which may be attributed to the intrinsic sensitivity of resonant measurements. Therefore, it can be said that nanomechanical biosensors demonstrate outstanding sensitivities for bacteria detection, comparable to the standard methods used at the clinic.

In addition to sensitivity, another important parameter to consider is the time to perform the analysis. Figure $\mathbf{5}$ shows the operation times of many reported nanomechanical sensors and some of the most widespread conventional methods for bacteria detection against their respective detection limits. Conventional techniques present excellent sensitivity but demand long analysis protocols. Growth-dependent approaches represent the most trusted gold-standard method; however, their main drawback is their necessity of culturing microorganisms in nourishing media for at least 16-24 h (for fast-growing bacteria) or days (for slow-growing bacteria) (Rajapaksha et al., 2019). On the other hand, culture-independent methods, such as polymerase chain reaction (PCR) and flow cytometry, can generate faster results (hours). PCR-based detection is precise and reliable, but it takes from 5 to $24 \mathrm{~h}$ depending on the specific variations and entails DNA extraction and thermocycled enzymatic polymerization, increasing the final costs (Valones et al., 2009; Emmadi et al., 2011). Flow cytometry allows highly sensitive analysis at the single cell level, involving the use of bulky and complex instrumentation (Valdez et al., 1997; Karo et al., 2008; AmbrizAviña et al., 2014). As depicted in the graph, nanomechanical sensors can generate quick results (from minutes to $<1 \mathrm{~h}$ ), yielding detection limits in a range that compares favorably with conventional methods. However, nanomechanical sensors still present limitations hindering their routine application in bacteria detection, discussed in more detail in section Conclusions and Future Perspectives.

\section{ANTIBIOTIC SUSCEPTIBILITY TESTING}

In recent years, rapid AST approaches based on advanced microand nanotechnologies have been proposed (Longo and Kasas, 2014; Syal et al., 2016, 2017b; Pujol-Vila et al., 2018). Among 
TABLE 1 | Main features of nanomechanical sensors for bacteria detection.

\begin{tabular}{|c|c|c|c|c|c|c|c|c|c|}
\hline & & Trasducer type & $\begin{array}{l}\text { Length } x \\
\text { thickness }\end{array}$ & $\begin{array}{l}\text { Detection } \\
\text { method }\end{array}$ & Medium & Bacteria & Functionalization & $\begin{array}{l}\text { Sensitivity or } \\
\text { LOD } \\
\text { performance }\end{array}$ & References \\
\hline \multirow[t]{23}{*}{ Dynamic } & $\begin{array}{l}\text { Bacteria } \\
\text { detection }\end{array}$ & Silicon Nitride MC & $300 \mu \mathrm{m} \times 320 \mathrm{~nm}$ & Optical beam & Air & E. coli & Antibody & 16 cells $(6 \mathrm{pg})$ & llic et al., 2000 \\
\hline & & Silicon nitride MC & $15 \mu \mathrm{m} \times 320 \mathrm{~nm}$ & Optical beam & Air & E. coli & Antibody & 1 cell & llic et al., 2001 \\
\hline & & Silicon MC & $78 \mu \mathrm{m} \times 0.3 \mu \mathrm{m}$ & $\begin{array}{l}\text { Laser Doppler } \\
\text { vibrometer }\end{array}$ & Air & Listeria innocua & antibody & $90 \mathrm{~Hz} / \mathrm{pg}$ (10 cells) & Gupta et al., 2004 \\
\hline & & Silicon MC & $430 \mu \mathrm{m} \times 1 \mu \mathrm{m}$ & Optical beam & Air & E. coli & None & 50 cells & Ramos et al., 2007b \\
\hline & & Silicon Nitride MC & $50 \mu \mathrm{m} \times 0.1 \mu \mathrm{m}$ & Optical beam & Vaccuum & E. coli $\mathrm{DH} 5 \mathrm{a}$ & Antibody & 1 cell & Malvar et al., 2016 \\
\hline & & Silicon disk & $2.5 \mu \mathrm{m}$ & Optical beam & Air & S. epidermidis & None & 1 cell & Gil-Santos et al., 2020 \\
\hline & & PZT MC (PEMC) & $3 \mathrm{~mm} \times 260 \mu \mathrm{m}$ & Electric & Liquid & S. cerevisiae & Poly-L-lysine & $\mathrm{ND}^{*}$ & Yi et al., 2003 \\
\hline & & PZT MC (PEMC) & $2 \mathrm{~mm} \times 127 \mu \mathrm{m}$ & Electric & Liquid & E. coli & Antibody & 700 cells $/ \mathrm{mL}$ & $\begin{array}{l}\text { Campbell and } \\
\text { Mutharasan, } 2005\end{array}$ \\
\hline & & PZT MC (PEMC) & $2 \mathrm{~mm} \times 127 \mu \mathrm{m}$ & Electric & Liquid & E. coli & Antibody & $1 \mathrm{cell} / \mathrm{ml}$ & Campbell et al., 2007a \\
\hline & & PZT MC (PEMC) & $1 \mathrm{~mm} \times 127 \mu \mathrm{m}$ & Electric & Liquid & E. coli & Antibody & 50-100 cells/mL & Campbell et al., 2007b \\
\hline & & PZT MC (PEMC) & $1 \mathrm{~mm} \times 127 \mu \mathrm{m}$ & Electric & Liquid & B. anthracis (spores) & Antibody & 300 spores $/ \mathrm{mL}$ & $\begin{array}{l}\text { Campbell and } \\
\text { Mutharasan, 2006a }\end{array}$ \\
\hline & & PZT MC (PEMC) & $1 \mathrm{~mm} \times 127 \mu \mathrm{m}$ & Electric & Liquid & B. anthracis (spores) & Antibody & $\begin{array}{l}2.89 \mathrm{fg} / \mathrm{Hz}(9 \\
\text { spores) }\end{array}$ & Campbell et al., 2007b \\
\hline & & PZT MC (PEMC) & $1 \mathrm{~mm} \times 127 \mu \mathrm{m}$ & Electric & Liquid & B. anthracis (spores) & Antibody & 38 spores $/ L$ & Campbell et al., 2007a \\
\hline & & PZT MC (PEMC) & $2 \mathrm{~mm} \times 127 \mu \mathrm{m}$ & Electric & Liquid & B. anthracis (spores) & Antibody & ND & McGovern et al., 2008 \\
\hline & & PZT MC (PEMC) & $5 \mathrm{~mm} \times 127 \mu \mathrm{m}$ & Electric & Liquid & L. monocytogenes & Antibody & 100 cells/mL & $\begin{array}{l}\text { Sharma and } \\
\text { Mutharasan, } 2013\end{array}$ \\
\hline & & Piezoelec. silicon AU-coated MC & $1 \mathrm{~mm} \times 127 \mu \mathrm{m}$ & Optical beam & Liquid & V. cholerae & Antibody & $10^{3} \mathrm{cfu} / \mathrm{mL}$ & Sungkanak et al., 2010 \\
\hline & & $\begin{array}{l}\text { Silicon cantilevers with gold } \\
\text { electrodes }\end{array}$ & $\mathrm{L} \times 10 \mu \mathrm{m}$ & $\begin{array}{l}\text { Vibrometry/ } \\
\text { electrokinetic }\end{array}$ & Liquid & E. coli & poly-L-lysine & $10^{8} \mathrm{cells} / \mathrm{ml}$ & Tomkins et al., 2013 \\
\hline & & $\begin{array}{l}\text { Silicon MC coated with piezoelectric } \\
\text { and gold }\end{array}$ & $420 u m \times 12 \mu \mathrm{m}$ & $\begin{array}{l}\text { Vibrometry/ } \\
\text { electrokinetic }\end{array}$ & Liquid & E. coli & Poly-L-Iysine & $326 \mathrm{fg} / \mathrm{Hz}$ & Leahy and Lai, 2017b \\
\hline & & $\begin{array}{l}\text { Silicon MC coated with piezoelectric } \\
\text { and gold }\end{array}$ & $200 \mu \mathrm{m} \times 10 \mu \mathrm{m}$ & $\begin{array}{l}\text { Vibrometry/ } \\
\text { electrokinetic }\end{array}$ & Liquid & E. coli & None & 100 cells/mL & Leahy and Lai, 2017a \\
\hline & & $\begin{array}{l}\text { Suspended silicon microchannel } \\
\text { (SMR) }\end{array}$ & $200 \mu \mathrm{m} \times 7 \mu \mathrm{m}$ & Optical beam & Vacuum & E. coli, B. subtilis & None & 1 cell & Burg et al., 2007 \\
\hline & & $\begin{array}{l}\text { Silicon MM with piezoelectric and } \\
\text { piezoresistor }\end{array}$ & $440 \mu \mathrm{m} \times 6 \mu \mathrm{m}$ & Resistive & Liquid & $\begin{array}{l}\text { B. atropheus } \\
\text { (spores) }\end{array}$ & Antibody & 800 spores $/ \mathrm{mL}$ & Alava et al., 2010 \\
\hline & $\begin{array}{l}\text { Microbial } \\
\text { growth }\end{array}$ & Silicon MC & $500 \mu \mathrm{m} \times 7 \mu \mathrm{m}$ & Optical beam & Liquid & E. coli & Agarose & ND & Gfeller et al., 2005a \\
\hline & & Silicon MC & $500 \mu \mathrm{m} \times 7 \mu \mathrm{m}$ & Optical beam & Liquid & E. coli & Agarose & $\begin{array}{l}50 \mathrm{pg} / \mathrm{Hz}(100 \\
\text { cells) }\end{array}$ & Gfeller et al., 2005b \\
\hline
\end{tabular}


TABLE 1 | Continued

\begin{tabular}{|c|c|c|c|c|c|c|c|c|c|}
\hline & & Trasducer type & $\begin{array}{l}\text { Length } x \\
\text { thickness }\end{array}$ & $\begin{array}{l}\text { Detection } \\
\text { method }\end{array}$ & Medium & Bacteria & Functionalization & $\begin{array}{l}\text { Sensitivity or } \\
\text { LOD } \\
\text { performance }\end{array}$ & References \\
\hline & & Silicon MC & $250 \mu \mathrm{m} \times 2 \mu \mathrm{m}$ & Optical beam & Liquid & $\begin{array}{l}\text { A. niger, } S \text {. } \\
\text { cerevisiae }\end{array}$ & $\lg G$, Con A & $\begin{array}{l}10^{3} \mathrm{cfu} / \mathrm{mL} 1.9 \\
\mathrm{pg} / \mathrm{Hz} \text { (1st mode) } \\
0.2 \mathrm{pg} / \mathrm{Hz} \text { (2nd } \\
\text { mode) }\end{array}$ & Nugaeva et al., 2005 \\
\hline & & $\begin{array}{l}\text { Suspended silicon microchannel } \\
\text { (SMR) }\end{array}$ & $200 \mu \mathrm{m} \times 7 \mu \mathrm{m}$ & Optical beam & Vacuum & E. coli, B. subtilis & None & sub-cell resolution & Godin et al., 2010 \\
\hline & & $\begin{array}{l}\text { Suspended silicon microchannel } \\
\text { (SMR) }\end{array}$ & $200 \mu \mathrm{m} \times 7 \mu \mathrm{m}$ & Optical beam & Vacuum & E. coli, E. faecalis & None & sub-cell resolution & Cermak et al., 2016 \\
\hline \multirow[t]{10}{*}{ Static } & $\begin{array}{l}\text { Bacteria } \\
\text { detection }\end{array}$ & $\begin{array}{l}\text { Gold-coated silicon nitride V-shaped } \\
\text { MC }\end{array}$ & $180 \mu \mathrm{m} \times 1 \mu \mathrm{m}$ & Optical beam & Liquid & E. coli O157:H7 & Antibodies & $10^{6} \mathrm{cfu} / \mathrm{mL}$ & Zhang and Ji, 2004 \\
\hline & & Silicon nitride V-shaped MC & $180 \mu \mathrm{m}$ & Optical beam & Liquid & Salmonella enterica & Antibodies & 25 cells & Weeks et al., 2006 \\
\hline & & Silicon gold-coated MC & $500 \mu \mathrm{m} \times 1 \mu \mathrm{m}$ & Optical beam & Liquid & Bacillus subtilis & Peptides & $10^{5}$ spores $/ \mathrm{mL}$ & Dhayal et al., 2006 \\
\hline & & Silicon gold-coated MC & $500 \mu \mathrm{m} \times 1 \mu \mathrm{m}$ & Optical beam & Liquid & E. coli & Glycans & $8-800$ bacterias & Mader et al., 2012 \\
\hline & & Silicon gold-coated MC & $500 \mu \mathrm{m} \times 1 \mu \mathrm{m}$ & Optical beam & Liquid & $\begin{array}{l}\text { Salmonella spp., L. } \\
\text { monocytog. \& E. coli }\end{array}$ & peptides & $\begin{array}{l}1 \times 10^{6} \mathrm{cfu} / \mathrm{mL} ; 1 \\
\times 10^{7} \mathrm{cfu} / \mathrm{mL}\end{array}$ & Wang et al., 2014 \\
\hline & & Silicon gold-coated MC & $500 \mu \mathrm{m} \times 1 \mu \mathrm{m}$ & Electric & Liquid & $\begin{array}{l}\text { E. coli, Vibrio, } \\
\text { Salmon., S. aureus }\end{array}$ & DNA & $1-9$ cells $/ \mathrm{mL}$ & Zheng et al., 2019 \\
\hline & & $\begin{array}{l}\text { Silicon nitride microfluidic gold-coated } \\
\text { MC }\end{array}$ & $600 \mu \mathrm{m} \times 3 \mu \mathrm{m}$ & Optical beam & Liquid & $\begin{array}{l}\text { Listeria monocytog., } \\
\text { E. coli }\end{array}$ & Antibodies & $1 \mathrm{cell} / \mathrm{uL}$ & Etayash et al., 2016 \\
\hline & & Polyimide microfluidic MC & $1.5 \mathrm{~mm} \times 48 \mu \mathrm{m}$ & Optical beam & Liquid & Cryptosporidium & Prot. G, IgG & $\begin{array}{l}1 \times \\
10^{5} \text { oocysts } / \mathrm{mL}\end{array}$ & Bridle et al., 2016 \\
\hline & & Gold-coated PDMS MM & $400 \mu \mathrm{m} \times 1 \mu \mathrm{m}$ & Interferometric & Liquid & E. coli & MUA & $\begin{array}{l}1.7 \times 10^{3} \mathrm{cell} / \mu \mathrm{L} \\
(20 \mu \mathrm{L})\end{array}$ & Sang and Witte, 2010 \\
\hline & & Gold-coated PDMS MM & $400 \mu \mathrm{m} \times 1 \mu \mathrm{m}$ & Capacitive & Liquid & S. aureus & Alkene-thiolate & $0.73 \mathrm{fF} /$ bacterium & Sang et al., 2015 \\
\hline
\end{tabular}

${ }^{*}$ Non-determined. 
them, nanomechanical sensors have a prominent position. In an early work, Ndieyira et al. studied the antibiotic-mucopeptide interactions with nanomechanical sensors (Ndieyira et al., 2008). In a later work, the surface forces generated by four antibiotics (vancomycin, ristomycin, chloroeremomycin, and oritavancin) against drug-susceptible and drug-resistant targets

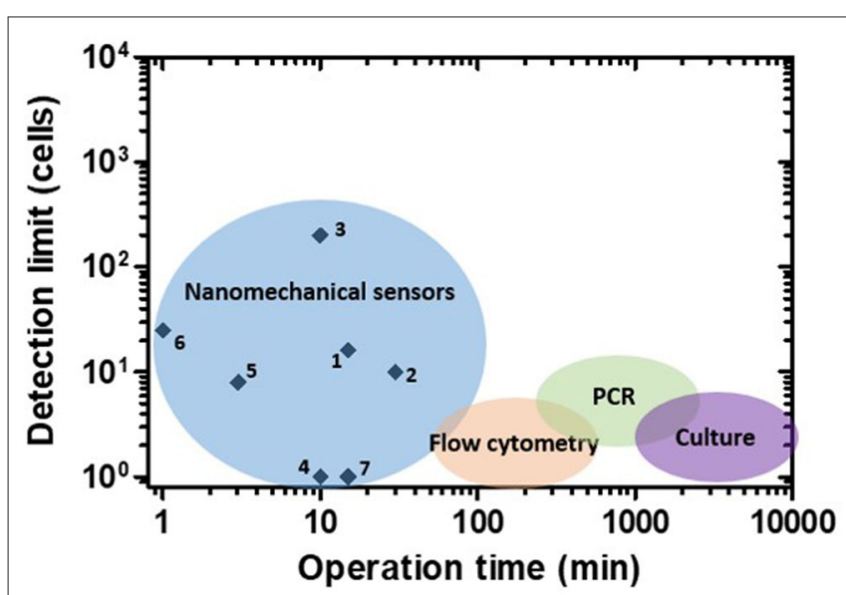

FIGURE 5 | Performance of nanomechanical sensors for bacteria detection. Operation time vs. detection limit plot for nanomechanical sensors and some of the most widespread conventional methods. Numbers correspond to references as follows: 1: llic et al. (2000), 2: Gupta et al. (2004), 3: Gfeller et al. (2005a), 4: Burg et al. (2007), 5: Mader et al. (2012), 6: Weeks et al. (2006), 7: Cermak et al. (2016). on cantilever were studied (Ndieyira et al., 2017). In 2013, Longo and coworkers reported the finding that bacterial metabolism could be measured by monitoring the fluctuations of staticmode cantilevers coated with the bacteria in aqueous medium (see Figures 6A,B), and applied this phenomenon to perform rapid AST (Longo et al., 2013). The detection was not based on classical static deflection or resonance frequency changes; instead, time-dependent fluctuations (background noise) of the transducer were analyzed. Living bacteria were covalently bound to both sides of silicon $\mathrm{v}$-shaped cantilevers using an aminosilane (APTES) as the linker molecule with good biocompatibility. The metabolic activity of attached E. coli and $S$. aureus induced low-frequency deflection fluctuations of the transducer. These nanoscale fluctuations were statistically analyzed and expressed in terms of variance. In the presence of the antibiotics ampicillin and kanamycin, the deflection fluctuations were drastically reduced due to bacterial killing by the drugs, allowing a rapid unraveling of the antibacterial effects. The obtained minimum inhibitory concentration (MIC), which is the standard quantitative indicator commonly used to determine antimicrobial susceptibility, was in agreement with standard AST techniques. Further investigation of the nanomotion induced by bacteria was carried out by imaging with fluorescence microscopy, revealing that cells attached to the apical region were responsible for the main contribution to the nanomechanical fluctuation. In addition, it was found that 50 cells were able to generate measurable fluctuations (Aghayee et al., 2013). These results demonstrate the suitability of this approach for accurate AST in $<1 \mathrm{~h}$ using low cell densities.

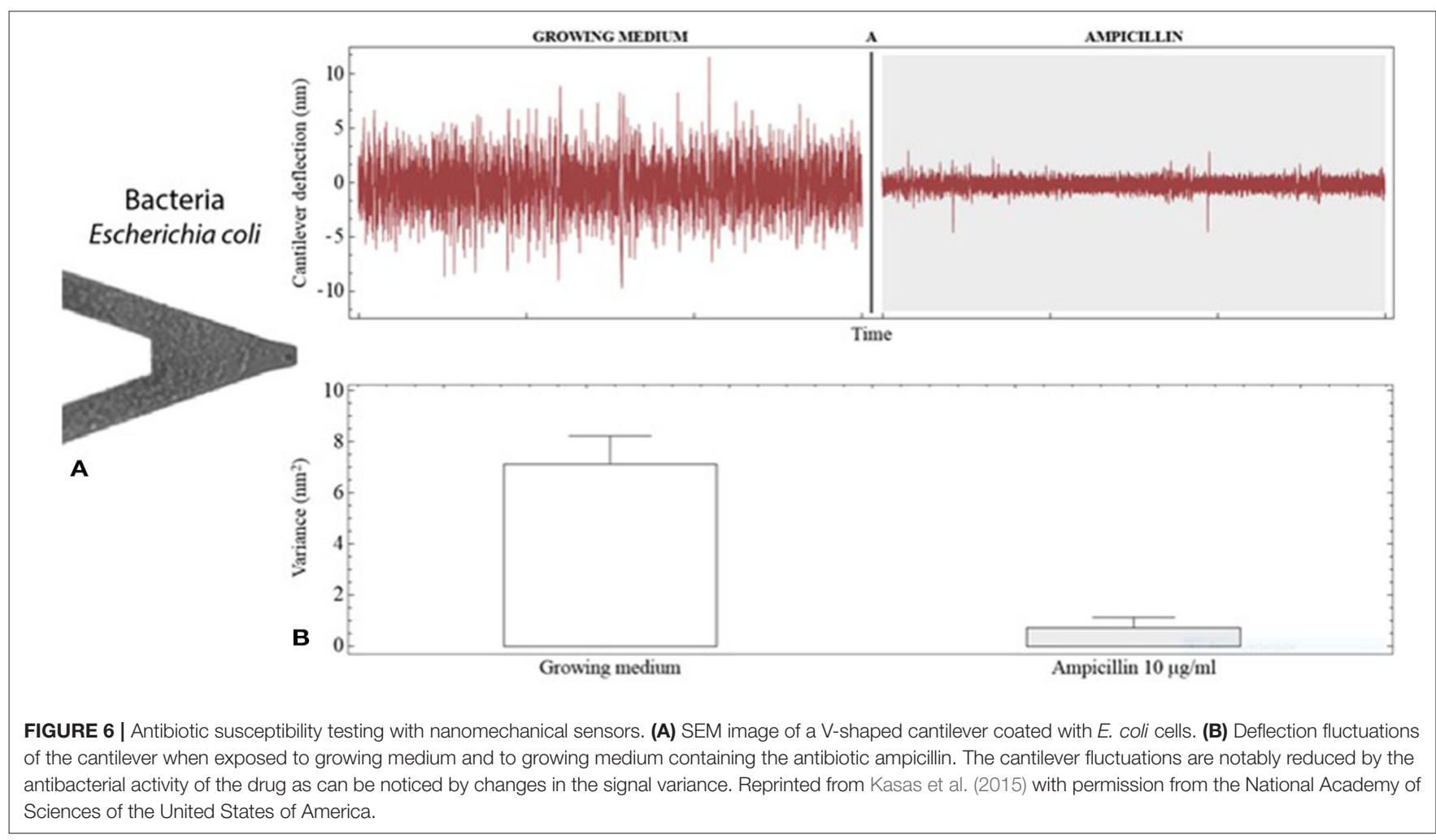


Mechanistically, the deflection fluctuations might originate from dynamics of the bacterial surface (cell wall and membrane), inner metabolic motion, or the activity of membrane protein pumps such as ATPases (molecular nano-motors) (Kohler et al., 2019).

Later, this detection scheme was successfully generalized to rectangular cantilevers and tested with many different organisms and antimicrobial compounds. Apart from Gram-negative and Gram-positive bacteria, the nanoscale fluctuations produced by the metabolic activity of fungi, osteoblasts, neurons, plant cells, and isolated mitochondria were measured and the effect of metabolic inhibitors was detected (Lissandrello et al., 2014; Kasas et al., 2015; Stupar et al., 2017a). The nanomechanical fluctuation-based AST was demonstrated also by Etayash et al. (2016) by using the previously described microfluidic cantilever (Figure 4), and $\mathrm{Wu}$ and coworkers applied this nanomechanical technology to the rapid screening of anticancer drugs (Wu et al., 2016). In order to transfer the nanomechanical AST to the clinical practice, the feasibility of using this technology with real bloodstream samples from infected patients was assessed. Blood cultures inoculated with susceptible and resistant E. coli strains were pelleted and immobilized on the cantilever. Then, the sensors were exposed to a selection of clinically relevant antibiotics (ciprofloxacin, ceftriaxone, and ampicillin) followed by double-blind evaluation of the data. Interestingly, more than $90 \%$ of the tested strains were positively discriminated as resistant or sensitive (with reference to standard methods) and a variance change of $60 \%$ was defined as a threshold to establish resistance/susceptibility (Stupar et al., 2017b).

Some bacterial pathogens present very slow growth rates and, hence, need very long incubation times (weeks or months) to proliferate in culture media, which delays clinical decision. By using the same nanomechanical AST, bacterium Bordetella pertussis (B. pertussis) and tuberculous bacillus Calmette-Guérin (Mycobacteria) were investigated as a model of slow-growing pathogens. Cantilevers coated with $B$. pertussis allowed the characterization of the sensitivity profile of the bacterium for many antibiotics in several hours (Villalba et al., 2018). The tuberculous bacillus Calmette-Guérin (a weakened strain of Mycobacterium bovis) and the non-tuberculous Mycobacterium abcessus were also tested, obtaining an MIC and a minimum bactericidal concentration (MBC) for different antimicrobials (bactericidal and bacteriostatic) in agreement with standard methods, demonstrating the feasibility of this technology for the fast assessment of slowly growing pathogens (Mustazzolu et al., 2019). To avoid issues related to the immobilization of the bacteria into the cantilever (i.e., number of bacteria, variability, and movement origin), Bennet et al. proposed, in a very recent work, the measurement of the spontaneous interference peaks of the optical signal due to the bacteria passing through the laser path (Bennett et al., 2020). The authors demonstrate the potential of this technique by determining resistance in both lab and clinical strains of E. coli within $45 \mathrm{~min}$ of the addition of antibiotic.

In the fight against bacterial infections, bacteriophages, i.e., viruses that infect bacteria, have been proposed as a promising alternative to antibiotic treatment (Gordillo Altamirano and Barr, 2019). In this regard, methods allowing quick evaluation of bacteria-bacteriophage interactions are needed. Mertens and coworkers used the nanomechanical technology to detect E. coli infection by T7 phages (Mertens et al., 2019) by combining both deflection and dynamic frequency-domain characterization. Cells were attached to poly-L-lysine coated silicon nitride cantilevers as shown in Figure $\mathbf{7 A}$, and exposed to the virus, showing that the biologically produced fluctuations were drastically reduced when bacterial infection occurred (Figures 7B,C).

All the described nanomechanical AST works are summarized in Table 2. Nanomechanical AST is a relatively recent application and has been mainly done by using silicon cantilevers combined with the optical beam detection technique. It is noteworthy to mention that the nanomechanical AST technology has been demonstrated working with many different bacteria and antimicrobial compounds. This detection scheme has evidenced sensitivity to a wide variety of bacterial species regardless of the cell size and shape, surface structure (Gramnegative and Gram-positive), and growth rate (fast- and slowgrowing). Moreover, antibiotics with diverse chemical nature and mechanisms of action, such as beta-lactams (inhibitors of cell wall synthesis), aminoglycosides and tetracyclines (inhibitors of protein synthesis), and sulphonamides (inhibitors of folate synthesis), among others, were successfully tested. In fact, bionanomechanical effects of both bactericidal and bacteriostatic drugs were detected, showing, in general terms, good agreement with conventional AST procedures (Kohler et al., 2019).

In Figure 8, MIC values obtained by nanomechanical AST and standard methods for the same antibiotics and bacterial strains are plotted against their respective operation times. Direct comparison of the MIC magnitude for every single strain and antibiotic reveals that the nanomechanical approach yields values similar to those reported by conventional methods. In contrast, important differences are found considering the operation time of the AST procedures. In this case, the conventional methods employed, microdilution and the proportion method, are growth-dependent, requiring at least $18 \mathrm{~h}$ for fast-growing bacteria and days/weeks for slowly growing bacteria (Syal et al., 2017a). As a rule, nanomechanical AST provided results in $1 \mathrm{~h}$ or less, demonstrating it is a much faster technique than the standard methods. According to this overall picture, the nanomechanical approach could provide great benefits in reducing the delay time between sample processing from patients and initiation of precise antimicrobial therapy.

\section{COMMERCIAL SYSTEMS}

Many companies dedicated to the commercialization of nanomechanical biosensors, with longer or shorter trajectories, have emerged during the last 20 years, applying the high sensitivity and fast response of this kind of biosensor to many different fields. Veecco, Protiveris, Concentris, and Cantion arose during the very beginning of the technology (Carrascosa et al., 2006), and companies such as Mecwins (two-dimensional scans for MEMS detection), Nanosensors (membrane-typesurface-stress sensors), Travera (SMR devices), and Tarabios 


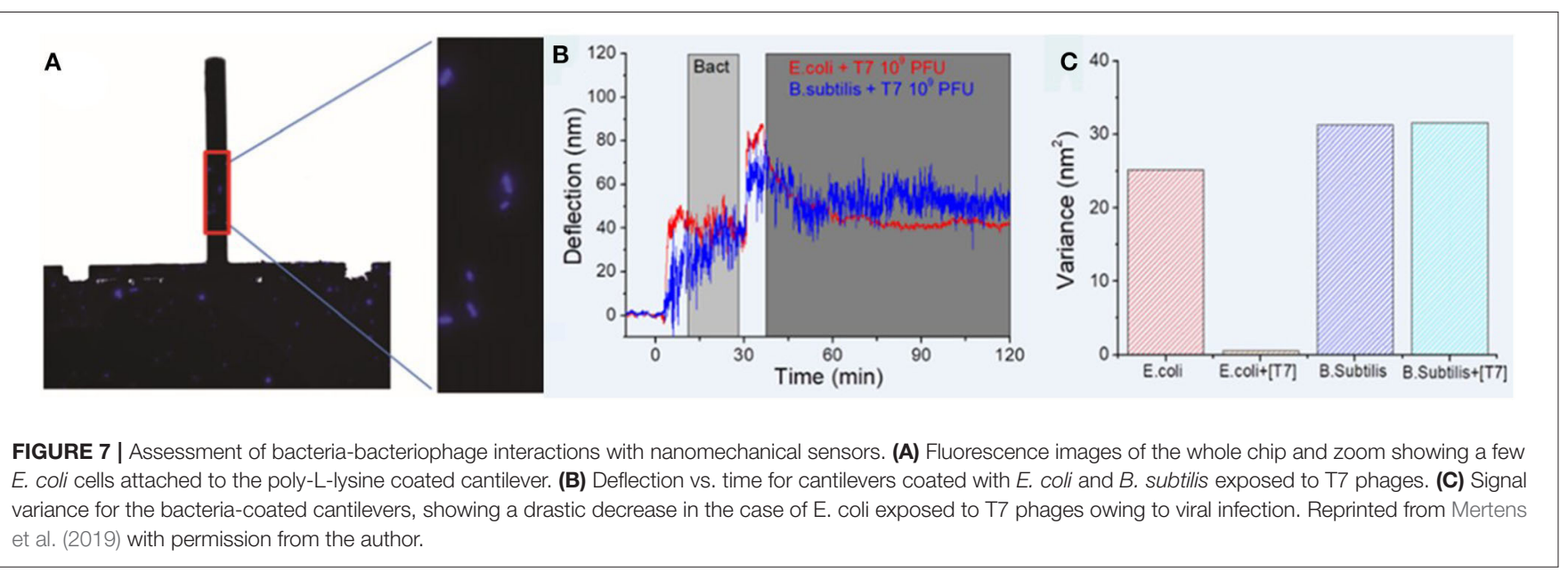

TABLE 2 | Main features of nanomechanical sensors for AST.

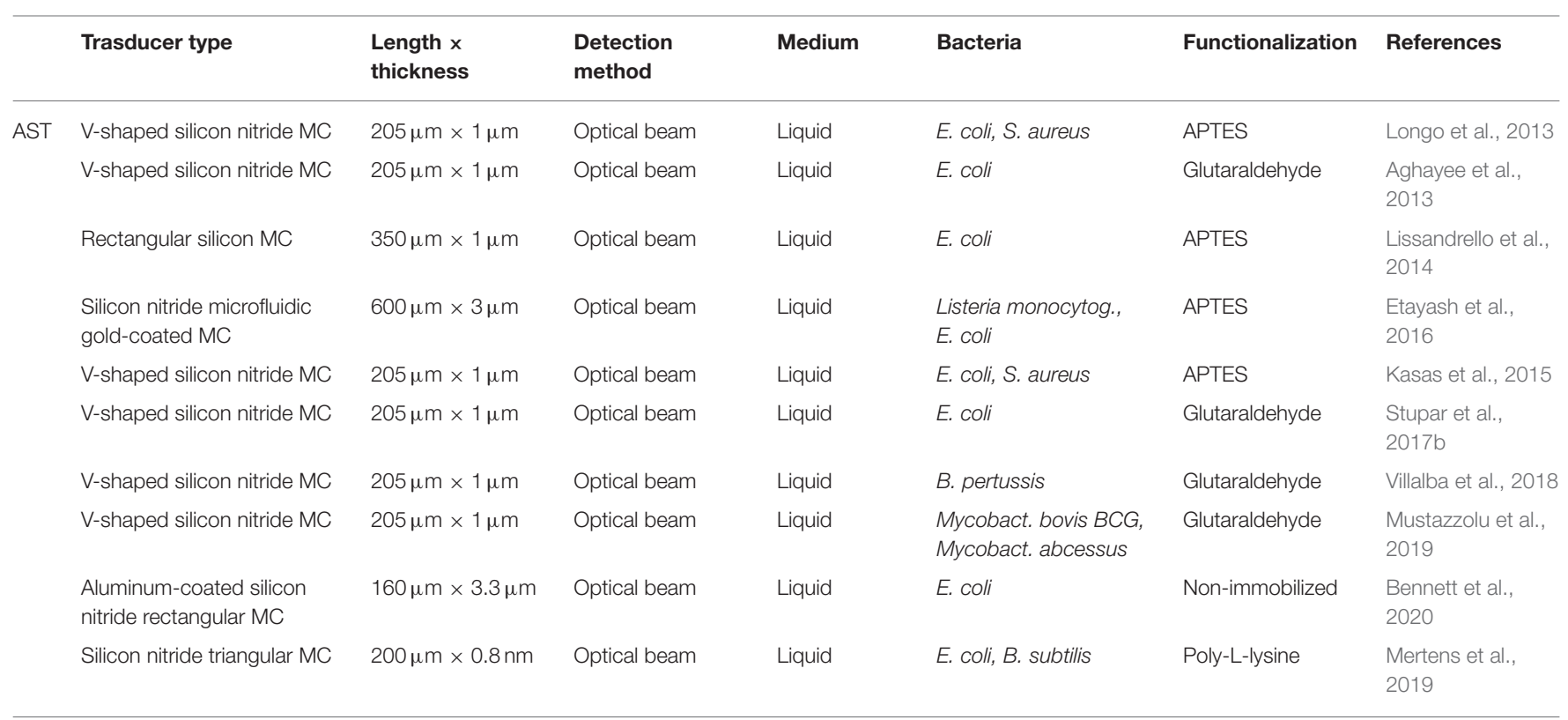

(fiber optic mechanical detection) have been emerging along the years, most of them as spin-off companies.

To the best of our knowledge, only a couple of commercial platforms based on nanomechanical sensors for bacteria detection and AST are available, using different modes of operation. Their main features are summarized in Table 3.

The LifeScale system ${ }^{\circledR}$, by Affinity Biosensors (Santa Barbara, CA, USA), exploits the previously explained silicon microchannel resonator (SMR) integrated in a microfluidic structure composed of a bypass channel (sample inlet) and a waste channel (outlet). When bacteria pass through the microchannel, the resonance frequency of the SMR diminishes proportional to the cell concentration. The commercial system uses an external piezo crystal to amplify the cantilever movement and an ion-implanted strain gage to measure the resonance frequency (instead of the optical detection method). The LifeScale system performs rapid AST based on biomass changes, which is a growth-dependent approach. AST can be performed directly from positive blood culture and urine samples if the concentration is above $10^{4} \mathrm{cfu}$ $\mathrm{mL}^{-1}$, providing AST data in 3-4h for fast-growing bacteria but taking much longer in the case of slowly growing bacteria (Puttaswamy et al., 2018).

The Resistell ${ }^{\mathrm{TM}}$ platform (Muttenz, Switzerland) proposes the use of AFM cantilevers coated with the bacteria to be tested and determines their metabolic activity in real time by measuring the low-frequency fluctuations of the transducer as explained before. When exposed to antibiotics, the nanomechanical fluctuations decrease proportional to the concentration of the drugs. This method is growth-independent because the bacterial metabolism is used as indicator. Hence, it allows very fast AST yielding results 
in 1-2 h even for slowly growing bacteria and represents one of the fastest emerging approaches. The main limitation of this strategy is, however, that it may need pretreatment of the sample or isolation of the target bacteria in order to avoid the presence of other cells (Puttaswamy et al., 2018).

\section{CONCLUSIONS AND FUTURE PERSPECTIVES}

In this review, we have provided a perspective on recent achievements in nanomechanical sensors applied to bacteria detection and AST with special focus on their performance with respect to conventional methods usually employed in clinical microbiology laboratories. Nanomechanical sensors have emerged as a promising technology in the management of bacterial infections thanks to (but not only) two main attributes: their excellent sensitivity and fast response time. These attributes allow label-free and sensitive bacteria detection and AST with an operation time of a few hours or minutes.

In spite of the huge advances, some technological challenges remain to be addressed to fully reach real sensing applications beyond the research environment. Some important issues are

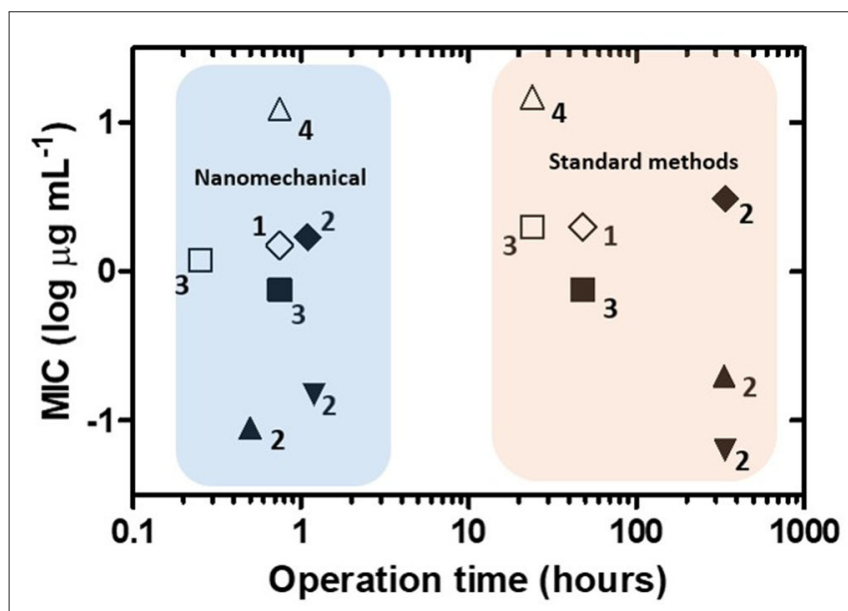

FIGURE 8 | Performance of nanomechanical sensors for antibiotic susceptibility testing. Operation time vs. minimum inhibitory concentration (MIC) plot for nanomechanical sensors and standard methods for the same antibiotics and bacterial strains. Symbols indicate each antibiotic/bacterial strain combination. Numbers correspond to references as follows: 1: Longo et al. (2013), 2: Mustazzolu et al. (2019), 3: Villalba et al. (2018), 4: Bennett et al. (2020). the signal stability and reproducibility and the effect of surface coating on the final sensitivity. Signal stability is affected by thermal drift, changing environments and noise, which could reduce the final reproducibility of the sensor. Another critical aspect is the robustness of the sensors when working with complex sample matrices, such as biological fluids/tissues or food/beverage samples. Some of the reported works need sample preprocessing, dilution, or purification steps to avoid unspecific bindings associated to the matrix components or negative effects on the detection methods (transparency of the media), which increases both time and cost of analysis. The sensors should allow direct analysis of complex biological samples, avoiding purification or dilution steps, similarly to the analysis currently performed using culture-based, flow cytometry, or PCR-based detection.

To date, nanomechanical sensor sensitivity is far beyond the single-cell level but requires high precision (and expensive) instrumentation for readout, either optical or electrical. The development of cost-effective, easy-to-use, and robust readout technologies represents a key milestone in order to democratize the nanomechanical sensing and reach routine application. Nevertheless, such low-cost readout schemes should not compromise sensor performance, keeping sensitivity levels suitable for their intended application. Future trends in nano/microfabrication technologies may improve miniaturization, integration, and reduce the cost of the sensing platform.

Bearing in mind that standard methods allow processing a large number of samples in parallel, the multidetection capability of nanomechanical sensors should be improved without greatly increasing costs or complexity of the detection system. Actually, the development of multiplexed readout schemes could play a beneficial role in reducing cost per analysis while enhancing the parallelization capacity. Current semiconductor technology allows the mass production, at low cost, of tens and hundreds of nanomechanical sensors into a single chip. However, two main drawbacks emerge in chasing high-throughput measurements: (i) poor scalability of the optic and electronic components with the number of sensors and (ii) reliable functionalization of dense arrays of suspended structures. The poor scalability of the readout components has limited the number of sensors measured simultaneously (below 10 sensors), being difficult to match the high-throughput capability of, for example, PCR techniques. Current commercially available high-throughput real-time PCR platforms allow the analysis of until 96 samples and 96 assays per sample in $<4 \mathrm{~h}$, using very low sample volume (>10 $\mathrm{nl}$ ) ${\text { (Dynamic } \text { Array }^{\mathrm{TM}} \text { chip from Fluidigm }}^{\circledR}$ ) (Lamas et al., 2016),

TABLE 3 | Commercial nanomechanical platforms for bacteria detection and AST.

\begin{tabular}{|c|c|c|c|c|c|}
\hline Platform & Goal & $\begin{array}{l}\text { Transducer/mode of } \\
\text { operation }\end{array}$ & Bioindicator & Time (h) & Direct from sample \\
\hline LifeScale system ${ }^{\circledR}$ & AST & SMR/dynamic & Growth & $3-4$ & Yes $^{\star}$ \\
\hline Resistell ${ }^{\mathrm{TM}}$ & AST & AFM cantilever/static & Metabolism & $1-2$ & No \\
\hline
\end{tabular}

*If the cell concentration is above $10^{4} \mathrm{cfu} \mathrm{mL}^{-1}$. 
which places nanomechanical sensors very far from being able to replace this type of technology in the near future. In return, PCR techniques suffer serious limitations, such as the necessity of prior information about the target sequence to generate the primers that will allow the DNA-selective amplification, being sensitive to mutations in the PCR fragments or the presence of contaminating DNA, which can be overcome by nanomechanical biosensors. On the contrary, culture-based methods are robust and less affected by interfering biological contaminants or traces, which make them highly reliable for pathogen detection. As mentioned before, however, they are time-consuming (days or weeks), thus postponing clinical decision and treatment while increasing the use of broad-spectrum antibiotics. The rapid nature of nanomechanical sensors holds great promise in shortening the gap between sample processing and results leading to improved clinical outcomes.

The moderate multisensing capability of nanomechancial sensors offers the possibility to detect different pathogens in a single sample, including controls in the same experiment. Along with the parallelization of sample analysis, the multidetection scheme allows the use of sensors as internal references, which help to improve the stability and reproducibility of the sensors by eliminating noise and signal drifts coming from variations in temperature, humidity, ionic strength, $\mathrm{pH}$, or unspecific bindings. Reference sensors can be passivated with specific molecules to improve the signal even more. To that end, each nanomechanical sensor in an array must be functionalized with a specific receptor layer, and it is necessary to have reliable methods able to deposit a low volume of samples (nL-pL) in very small areas $\left(\sim 4,000 \mu \mathrm{m}^{2}\right)$ and with high precision to avoid cross-functionalization of neighboring sensors (usually separated $\sim 250 \mu \mathrm{m}$ ). These necessities make the functionalization process not straightforward and more complex than for other kinds of biosensors (i.e., by including alignment steps).

\section{REFERENCES}

Aghayee, S., Benadiba, C., Notz, J., Kasas, S., Dietler, G., and Longo, G. (2013). Combination of fluorescence microscopy and nanomotion detection to characterize bacteria. J. Mol. Recognit. 26, 590-595. doi: 10.1002/ jmr.2306

Ahmed, A., Rushworth, J. V., Hirst, N. A., and Millner, P. A. (2014). Biosensors for whole-cell bacterial detection. Clin. Microbiol. Rev. 27, 631-646. doi: 10.1128/CMR.00120-13

Alava, T., Mathieu, F., Rameil, P., Morel, Y., Soyer, C., Remiens, D., et al. (2010). Piezoelectric-actuated, piezoresistive-sensed circular micromembranes for label-free biosensing applications. Appl. Phys. Lett. 97:093703. doi: $10.1063 / 1.3486112$

Álvarez, M., Carrascosa, L. G., Moreno, M., Calle, A., Zaballos, Á., Lechuga, L. M., et al. (2004). Nanomechanics of the formation of DNA self-assembled monolayers and hybridization on microcantilevers. Langmuir 20, 9663-9668. doi: 10.1021/la0489559

Alvarez, M., and Lechuga, L. M. (2010). Microcantilever-based platforms as biosensing tools. Analyst 135, 827-836. doi: 10.1039/b908503n

Ambriz-Aviña, V., Contreras-Garduño, J. A., and Pedraza-Reyes, M. (2014). Applications of flow cytometry to characterize bacterial physiological responses. Biomed Res. Int. 2014:461941. doi: 10.1155/2014/461941

Arlett, J. L., Myers, E. B., and Roukes, M. L. (2011). Comparative advantages of mechanical biosensors. Nat. Nanotech. 6, 203-215. doi: 10.1038/nnano.2011.44
In conclusion, the ultra-sensitive nature of the nanomechanical technology has opened new possibilities in the diagnostics of infectious diseases by overcoming some critical limitations of conventional methods, but it is still far from being a mature technology ready to replace the gold standard methods. Nanomechanical sensors offers the label-free detection of very low concentrations of pathogenic DNA (fM) without pre-amplification steps, detection of single bacteria, AST analysis, and moderate multidetection capability (not high-throughput), all of them in short operation times $(\leq 1 \mathrm{~h})$. The high sensitivity and fast response of this technology, joined to its easy integration with microfluidic systems, may provide an interesting alternative for the detection and identification of bacteria and AST analysis, both in the laboratory and at the point of care. Further research needs to be done to increase the stability, robustness, and parallelization performance and, at the same time, reduce the cost and complexity of the detection system and, thus, achieve an affordable and easy-to-use platform that does not require specialized personnel. In the near future, nanomechanical sensors might evolve into a key enabling technology with high potential of impact in human health and well-being.

\section{AUTHOR CONTRIBUTIONS}

FP-V collected the data and led the writing. RV and MA made the critical review of article content and writing. All authors contributed to the article and approved the submitted version.

\section{FUNDING}

This work was financially supported by the Ministerio de Ciencia Innovación y Universidades, through GUMICHIP project (RTI2018-096786-B-I00).

Aslam, B., Wang, W., Arshad, M. I., Khurshid, M., Muzammil, S., Rasool, M. H., et al. (2018). Antibiotic resistance: a rundown of a global crisis. Infect. Drug Resist. 11, 1645-1658. doi: 10.2147/IDR.S173867

Bausells, J. (2015). Piezoresistive cantilevers for nanomechanical sensing. Microelectron. Eng. 145, 9-20. doi: 10.1016/j.mee.2015.02.010

Behera, B., Anil Vishnu, G. K., Chatterjee, S., Sitaramgupta V, V. S. N., Sreekumar, N., Nagabhushan, A., et al. (2019). Emerging technologies for antibiotic susceptibility testing. Biosens. Bioelectron. 142:111552. doi: 10.1016/j.bios.2019.111552

Bennett, I., Pyne, A., and McKendry, R. (2020). Cantilever sensors for rapid optical antimicrobial sensitivity testing. bioRxiv [Preprint]. doi: 10.1101/679399

Bietsch, A., Zhang, J., Hegner, M., Lang, H. P., and Gerber, C. (2004). Rapid functionalization of cantilever array sensors by inkjet printing. Nanotechnology 15, 873-880. doi: 10.1088/0957-4484/15/8/002

Bloom, D. E., and Cadarette, D. (2019). Infectious disease threats in the twentyfirst century: strengthening the global response. Front. Immunol. 10:549. doi: 10.3389/fimmu.2019.00549

Bridle, H., Wang, W., Gavriilidou, D., Amalou, F., Hand, D. P., and Shu, W. (2016). Static mode microfluidic cantilevers for detection of waterborne pathogens. Sens. Actuators A Phys. 247, 144-149. doi: 10.1016/j.sna.2016. 05.011

Burg, T. P., Godin, M., Knudsen, S. M., Shen, W., Carlson, G., Foster, J. S., et al. (2007). Weighing of biomolecules, single cells and single nanoparticles in fluid. Nature 446, 1066-1069. doi: 10.1038/nature05741 
Burg, T. P., and Manalis, S. R. (2003). Suspended microchannel resonators for biomolecular detection. Appl. Phys. Lett. 83, 2698-2700. doi: 10.1063/1.1611625

Campbell, G. A., deLesdernier, D., and Mutharasan, R. (2007a). Detection of airborne Bacillus anthracis spores by an integrated system of an air sampler and a cantilever immunosensor. Sens. Actuators B Chem. 127, 376-382. doi: 10.1016/j.snb.2007.04.038

Campbell, G. A., and Mutharasan, R. (2005). Detection of pathogen Escherichia coli O157:H7 using self-excited PZT-glass microcantilevers. Biosens. Bioelectron. 21, 462-473. doi: 10.1016/j.bios.2004.11.009

Campbell, G. A., and Mutharasan, R. (2006a). Piezoelectric-excited millimetersized cantilever (PEMC) sensors detect Bacillus anthracis at 300spores $/ \mathrm{mL}$. Biosens. Bioelectron. 21, 1684-1692. doi: 10.1016/j.bios.2005.08.001

Campbell, G. A., and Mutharasan, R. (2006b). Use of piezoelectric-excited millimeter-sized cantilever sensors to measure albumin interaction with selfassembled monolayers of alkanethiols having different functional headgroups. Anal. Chem. 78, 2328-2334. doi: 10.1021/ac0517491

Campbell, G. A., and Mutharasan, R. (2007a). A method of measuring Escherichia Coli $\mathrm{O} 157: \mathrm{H} 7$ at $1 \mathrm{cell} / \mathrm{mL}$ in 1 liter sample using antibody functionalized piezoelectric-excited millimeter-sized cantilever sensor. Environ. Sci. Technol. 41, 1668-1674. doi: 10.1021/es061947p

Campbell, G. A., and Mutharasan, R. (2007b). Method of measuring Bacillus anthracis spores in the presence of copious amounts of Bacillus thuringiensis and Bacillus cereus. Anal. Chem. 79, 1145-1152. doi: 10.1021/ac060982b

Campbell, G. A., Uknalis, J., Tu, S.-I., and Mutharasan, R. (2007b). Detect of Escherichia coli O157:H7 in ground beef samples using piezoelectric excited millimeter-sized cantilever (PEMC) sensors. Biosens. Bioelectron. 22, 1296-1302. doi: 10.1016/j.bios.2006.05.028

Carrascosa, L. G., Moreno, M., Álvarez, M., and Lechuga, L. M. (2006). Nanomechanical biosensors: a new sensing tool. TrAC Trends Anal. Chem. 25, 196-206. doi: 10.1016/j.trac.2005.09.006

Cermak, N., Olcum, S., Delgado, F. F., Wasserman, S. C., Payer, K. R., Murakami, M. A., et al. (2016). High-throughput measurement of single-cell growth rates using serial microfluidic mass sensor arrays. Nat. Biotechnol. 34, 1052-1059. doi: $10.1038 /$ nbt.3666

Chatzipetrou, M., Tsekenis, G., Tsouti, V., Chatzandroulis, S., and Zergioti, I. (2013). Biosensors by means of the laser induced forward transfer technique. Appl. Surf. Sci. 278, 250-254. doi: 10.1016/j.apsusc.2012.11.064

Davila, A. P., Jang, J., Gupta, A. K., Walter, T., Aronson, A., and Bashir, R. (2007). Microresonator mass sensors for detection of Bacillus anthracis Sterne spores in air and water. Biosens. Bioelectron. 22, 3028-3035. doi: 10.1016/j.bios.2007.01.012

Dhayal, B., Henne, W. A., Doorneweerd, D. D., Reifenberger, R. G., and Low, P. S. (2006). Detection of Bacillus $s$ ubtilis spores using peptide-functionalized cantilever arrays. J. Am. Chem. Soc. 128, 3716-3721. doi: 10.1021/ja05 70887

Dinarelli, S., Girasole, M., Kasas, S., and Longo, G. (2017). Nanotools and molecular techniques to rapidly identify and fight bacterial infections. J. Microbiol. Methods 138, 72-81. doi: 10.1016/j.mimet.2016.01.005

Emmadi, R., Boonyaratanakornkit, J. B., Selvarangan, R., Shyamala, V., Zimmer, B. L., Williams, L., et al. (2011). Molecular methods and platforms for infectious diseases testing. The J. Mol. Diagn. 13, 583-604. doi: 10.1016/j.jmoldx.2011.05.011

Etayash, H., Jiang, K., Azmi, S., Thundat, T., and Kaur, K. (2015). Real-time detection of breast cancer cells using peptide-functionalized microcantilever arrays. Sci. Rep. 5:13967. doi: 10.1038/srep13967

Etayash, H., Khan, M. F., Kaur, K., and Thundat, T. (2016). Microfluidic cantilever detects bacteria and measures their susceptibility to antibiotics in small confined volumes. Nat. Commun. 7:12947. doi: 10.1038/ncomms12947

Fritz, J. (2000). Translating biomolecular recognition into nanomechanics. Science 288, 316-318. doi: 10.1126/science.288.5464.316

Fritz, J. (2008). Cantilever biosensors. Analyst 133:855. doi: 10.1039/b718174d

Gfeller, K. Y., Nugaeva, N., and Hegner, M. (2005a). Micromechanical oscillators as rapid biosensor for the detection of active growth of Escherichia coli. Biosens. Bioelectron. 21, 528-533. doi: 10.1016/j.bios.2004.11.018

Gfeller, K. Y., Nugaeva, N., and Hegner, M. (2005b). Rapid biosensor for detection of antibiotic-selective growth of Escherichia coli. Appl. Environ. Microbiol. 71, 2626-2631. doi: 10.1128/AEM.71.5.2626-2631.2005
Gil-Santos, E., Ruz, J. J., Malvar, O., Favero, I., Lemaître, A., Kosaka, P. M., et al. (2020). Optomechanical detection of vibration modes of a single bacterium. Nat. Nanotechnol. 15, 469-474. doi: 10.1038/s41565-020-0698-1

Godin, M., Delgado, F. F., Son, S., Grover, W. H., Bryan, A. K., Tzur, A., et al. (2010). Using buoyant mass to measure the growth of single cells. Nat. Methods 7, 387-390. doi: 10.1038/nmeth.1452

Gordillo Altamirano, F. L., and Barr, J. J. (2019). Phage therapy in the postantibiotic Era. Clin. Microbiol. Rev. 32:e00066-18. doi: 10.1128/CMR.00066-18

Gruber, G., Urgell, C., Tavernarakis, A., Stavrinadis, A., Tepsic, S., Magén, C., et al. (2019). Mass sensing for the advanced fabrication of nanomechanical resonators. Nano Lett. 19, 6987-6992. doi: 10.1021/acs.nanolett.9b02351

Gupta, A., Akin, D., and Bashir, R. (2004). Detection of bacterial cells and antibodies using surface micromachined thin silicon cantilever resonators. $J$. Vac. Sci. Technol. B 22, 2785. doi: 10.1116/1.1824047

Hajjaj, A. Z., Jaber, N., Ilyas, S., Alfosail, F. K., and Younis, M. I. (2020). Linear and nonlinear dynamics of micro and nano-resonators: Review of recent advances. Int. J. Non Linear Mech. 119:103328. doi: 10.1016/j.jinonlinmec.2019.103328

Hansen, K. M., and Thundat, T. (2005). Microcantilever biosensors. Methods 37, 57-64. doi: 10.1016/j.ymeth.2005.05.011

Ilic, B., Czaplewski, D., Craighead, H. G., Neuzil, P., Campagnolo, C., and Batt, C. (2000). Mechanical resonant immunospecific biological detector. Appl. Phys. Lett. 77, 450-452. doi: 10.1063/1.127006

Ilic, B., Czaplewski, D., Zalalutdinov, M., Craighead, H. G., Neuzil, P., Campagnolo, C., et al. (2001). Single cell detection with micromechanical oscillators. J. Vac. Sci. Technol. B 19:2825. doi: 10.1116/1.1421572

Imamura, G., Shiba, K., and Yoshikawa, G. (2016). Finite element analysis on nanomechanical sensing of cellular forces. Anal. Sci. 32, 1189-1194. doi: $10.2116 /$ analsci. 32.1189

Jajere, S. M. (2019). A review of Salmonella enterica with particular focus on the pathogenicity and virulence factors, host specificity and antimicrobial resistance including multidrug resistance. Vet World 12, 504-521. doi: 10.14202/vetworld.2019.504-521

Jian, A., Tang, X., Feng, Q., Duan, Q., Ji, J., Ma, Z., et al. (2017). A PDMS surface stress biosensor with optimized micro-membrane: fabrication and application. Sens. Actuators B Chem. 242, 969-976. doi: 10.1016/j.snb.2016.09.157

Jin, D., Li, X., Liu, J., Zuo, G., Wang, Y., Liu, M., et al. (2006). High-mode resonant piezoresistive cantilever sensors for tens-femtogram resoluble mass sensing in air. J. Micromech. Microeng. 16, 1017-1023. doi: 10.1088/0960-1317/16/5/019

Johnson, B. N., and Mutharasan, R. (2012). Biosensing using dynamicmode cantilever sensors: a review. Biosens. Bioelectron. 32, 1-18. doi: 10.1016/j.bios.2011.10.054

Karo, O., Wahl, A., Nicol, S.-B., Brachert, J., Lambrecht, B., Spengler, H.-P., et al. (2008). Bacteria detection by flow cytometry. Clin. Chem. Lab. Med. 46, 947-53. doi: 10.1515/CCLM.2008.156

Kasas, S., Ruggeri, F. S., Benadiba, C., Maillard, C., Stupar, P., Tournu, H., et al. (2015). Detecting nanoscale vibrations as signature of life. Proc. Natl. Acad. Sci. U.S.A. 112, 378-381. doi: 10.1073/pnas.1415348112

Kim, J., Kim, H. J., Cho, E., Shin, H.-J., Park, J. H., and Hwang, K. S. (2015). Enhancing the sensitivity of a micro-diaphragm resonating sensor by effectively positioning the mass on the membrane. Sci. Rep. 5:17069. doi: 10.1038/srep17069

Kohler, A. C., Venturelli, L., Longo, G., Dietler, G., and Kasas, S. (2019). Nanomotion detection based on atomic force microscopy cantilevers. Cell Surf. 5:100021. doi: 10.1016/j.tcsw.2019.100021

Lamas, A., Franco, C. M., Regal, P., Miranda, J. M., Vázquez, B., and Cepeda, A. (2016). "High-throughput platforms in real-time PCR and applications," in Polymerase Chain Reaction for Biomedical Applications (IntechOpen). doi: $10.5772 / 65760$

Leahy, S., and Lai, Y. (2017a). A cantilever biosensor based on a gap method for detecting Escherichia coli in real time. Sens. Actuators B Chem. 246, 1011-1016. doi: 10.1016/j.snb.2017.02.144

Leahy, S., and Lai, Y. (2017b). A cantilever biosensor exploiting electrokinetic capture to detect Escherichia coli in real time. Sens. Actuators B Chem. 238, 292-297. doi: 10.1016/j.snb.2016.07.069

Leonard, H., Colodner, R., Halachmi, S., and Segal, E. (2018). Recent advances in the race to design a rapid diagnostic test for antimicrobial resistance. ACS Sens. 3, 2202-2217. doi: 10.1021/acssensors.8b00900 
Li, Y., Yang, X., and Zhao, W. (2017). Emerging microtechnologies and automated systems for rapid bacterial identification and antibiotic susceptibility testing. SLAS Technol. 22, 585-608. doi: 10.1177/2472630317727519

Lissandrello, C., Inci, F., Francom, M., Paul, M. R., Demirci, U., and Ekinci, K. L. (2014). Nanomechanical motion of Escherichia coli adhered to a surface. Appl. Phys. Lett. 105:113701. doi: 10.1063/1.4895132

Loizeau, F., Akiyama, T., Gautsch, S., Vettiger, P., Yoshikawa, G., and de Rooij, N. F. (2015). Comparing membrane- and cantilever-based surface stress sensors for reproducibility. Sens. Actuators A Phys. 228, 9-15. doi: 10.1016/j.sna.2015.02.039

Longo, G., Alonso-Sarduy, L., Rio, L. M., Bizzini, A., Trampuz, A., Notz, J., et al. (2013). Rapid detection of bacterial resistance to antibiotics using AFM cantilevers as nanomechanical sensors. Nat. Nanotech. 8, 522-526. doi: $10.1038 /$ nnano. 2013.120

Longo, G., and Kasas, S. (2014). Effects of antibacterial agents and drugs monitored by atomic force microscopy: AFM study of the effects of antibacterial agents and drugs. WIREs Nanomed. Nanobiotechnol. 6, 230-244. doi: 10.1002/wnan.1258

Mader, A., Gruber, K., Castelli, R., Hermann, B. A., Seeberger, P. H., Rädler, J. O., et al. (2012). Discrimination of Escherichia coli strains using glycan cantilever array sensors. Nano Lett. 12, 420-423. doi: 10.1021/nl203736u

Malvar, O., Ruz, J. J., Kosaka, P. M., Domínguez, C. M., Gil-Santos, E., Calleja, M., et al. (2016). Mass and stiffness spectrometry of nanoparticles and whole intact bacteria by multimode nanomechanical resonators. Nat. Commun. 7:13452. doi: 10.1038/ncomms 13452

Mannoor, M. S., Tao, H., Clayton, J. D., Sengupta, A., Kaplan, D. L., Naik, R. R., et al. (2012). Graphene-based wireless bacteria detection on tooth enamel. Nat. Commun. 3:763. doi: 10.1038/ncomms 1767

Maruyama, S., Hizawa, T., Takahashi, K., and Sawada, K. (2018). Opticalinterferometry-based CMOS-MEMS sensor transduced by stress-induced nanomechanical deflection. Sensors 18:138. doi: 10.3390/s18010138

Mathew, R., and Ravi Sankar, A. (2018). A review on surface stress-based miniaturized piezoresistive SU-8 polymeric cantilever sensors. Nano Micro Lett. 10:35. doi: $10.1007 /$ s40820-018-0189-1

McGovern, J.-P., Shih, W. Y., Rest, R., Purohit, M., Pandya, Y., and Shih, W.-H. (2008). Label-free flow-enhanced specific detection of Bacillus anthracis using a piezoelectric microcantilever sensor. Analyst 133:649. doi: 10.1039/b715948j

Mertens, J., Cuervo, A., and Carrascosa, J. L. (2019). Nanomechanical detection of Escherichia coli infection by bacteriophage T7 using cantilever sensors. Nanoscale 11, 17689-17698. doi: 10.1039/C9NR05240B

Minami, K., and Yoshikawa, G. (2020). Finite element analysis of interface dependence on nanomechanical sensing. Sensors 20:1518. doi: $10.3390 / \mathrm{s} 20051518$

Mustazzolu, A., Venturelli, L., Dinarelli, S., Brown, K., Floto, R. A., Dietler, G., et al. (2019). A Rapid unraveling of the activity and antibiotic susceptibility of mycobacteria. Antimicrob. Agents Chem. 63:e2194-18. doi: 10.1128/AAC.02194-18

Mutharasan, R. (2008). "Cantilever sensors for pathogen detection," in Principles of Bacterial Detection: Biosensors, Recognition Receptors and Microsystems, eds M. Zourob, S. Elwary, and A. Turner (New York, NY: Springer), 459-480.

Ndieyira, J. W., Bailey, J., Patil, S. B., Vögtli, M., Cooper, M. A., Abell, C., et al. (2017). Surface mediated cooperative interactions of drugs enhance mechanical forces for antibiotic action. Sci. Rep. 7:41206. doi: 10.1038/srep41206

Ndieyira, J. W., Watari, M., Barrera, A. D., Zhou, D., Vögtli, M., Batchelor, M., et al. (2008). Nanomechanical detection of antibiotic-mucopeptide binding in a model for superbug drug resistance. Nat. Nanotech. 3, 691-696. doi: $10.1038 /$ nnano.2008.275

Nguyen, Y., and Sperandio, V. (2012). Enterohemorrhagic E. coli (EHEC) pathogenesis. Front. Cell. Inf. Microbiol. 2:90. doi: 10.3389/fcimb.2012.00090

Nikkhoo, N., Cumby, N., Gulak, P. G., and Maxwell, K. L. (2016). Rapid bacterial detection via an all-electronic CMOS biosensor. PLoS One 11:e0162438. doi: 10.1371/journal.pone.0162438

Nugaeva, N., Gfeller, K. Y., Backmann, N., Lang, H. P., Düggelin, M., and Hegner, M. (2005). Micromechanical cantilever array sensors for selective fungal immobilization and fast growth detection. Biosens. Bioelectron. 21, 849-856. doi: 10.1016/j.bios.2005.02.004

Okeke, I. N., Peeling, R. W., Goossens, H., Auckenthaler, R., Olmsted, S. S., de Lavison, J.-F., et al. (2011). Diagnostics as essential tools for containing antibacterial resistance. Drug Resist. Updat. 14, 95-106. doi: 10.1016/j.drup.2011.02.002

Park, K., Millet, L. J., Kim, N., Li, H., Jin, X., Popescu, G., et al. (2010). Measurement of adherent cell mass and growth. Proc. Natl. Acad. Sci. U.S.A. 107, 20691-20696. doi: 10.1073/pnas.1011365107

Patil, S. B., Al-Jehani, R. M., Etayash, H., Turbe, V., Jiang, K., Bailey, J., et al. (2018). Modified cantilever arrays improve sensitivity and reproducibility of nanomechanical sensing in living cells. Commun. Biol. 1:175. doi: 10.1038/s42003-018-0179-3

Pujol-Vila, F., Dietvorst, J., Gall-Mas, L., Díaz-González, M., Vigués, N., Mas, J., et al. (2018). Bioelectrochromic hydrogel for fast antibiotic-susceptibility testing. J. Colloid Interface Sci. 511, 251-258. doi: 10.1016/j.jcis.201 7.09 .004

Puttaswamy, S., Gupta, S. K., Regunath, H., Smith, L. P., and Sengupta, S. (2018). A comprehensive review of the present and future Antibiotic Susceptibility Testing (AST) systems. Arch. Clin. Microbiol. 9:83. doi: 10.4172/1989-8436.100083

Qu, H., and Xie, H. (2012). "CMOS MEMS fabrication technologies," in Encyclopedia of Nanotechnology, ed B. Bhushan (Dordrecht: Springer Netherlands), 441-449.

Rajapaksha, P., Elbourne, A., Gangadoo, S., Brown, R., Cozzolino, D., and Chapman, J. (2019). A review of methods for the detection of pathogenic microorganisms. Analyst 144, 396-411. doi: 10.1039/C8AN01488D

Ramos, D., Calleja, M., Mertens, J., Zaballos, Á., and Tamayo, J. (2007a). Measurement of the mass and rigidity of adsorbates on a microcantilever sensor. Sensors 7, 1834-1845. doi: 10.3390/s7091834

Ramos, D., Tamayo, J., Mertens, J., Calleja, M., Villanueva, L. G., and Zaballos, A. (2007b). Detection of bacteria based on the thermomechanical noise of a nanomechanical resonator: origin of the response and detection limits. Nanotechnology 19:035503. doi: 10.1088/0957-4484/19/03/035503

Roy, S. K., Sauer, V. T. K., Westwood-Bachman, J. N., Venkatasubramanian, A., and Hiebert, W. K. (2018). Improving mechanical sensor performance through larger damping. Science 360:aar5220. doi: 10.1126/science.aar5220

Sage, E., Sansa, M., Fostner, S., Defoort, M., Gély, M., Naik, A. K., et al. (2018). Single-particle mass spectrometry with arrays of frequency-addressed nanomechanical resonators. Nat. Commun. 9:3283. doi: 10.1038/s41467-018-05783-4

Sang, S., Feng, Q., Tang, X., Wang, T., Huang, X., Jian, A., et al. (2015). PDMS micro-membrane capacitance-type surface stress biosensors for biomedical analyses. Microelectron. Eng. 134, 33-37. doi: 10.1016/j.mee.201 5.01 .030

Sang, S., and Witte, H. (2010). A novel PDMS micro membrane biosensor based on the analysis of surface stress. Biosens. Bioelectron. 25, 2420-2424. doi: 10.1016/j.bios.2010.03.035

Sharma, H., and Mutharasan, R. (2013). Rapid and sensitive immunodetection of Listeria monocytogenes in milk using a novel piezoelectric cantilever sensor. Biosens. Bioelectron. 45, 158-162. doi: 10.1016/j.bios.2013.01.068

Shin, D. J., Andini, N., Hsieh, K., Yang, S., and Wang, T.-H. (2019). Emerging analytical techniques for rapid pathogen identification and susceptibility testing. Annu. Rev. Anal. Chem. 12, 41-67. doi: 10.1146/annurev-anchem-061318-115529

Singamaneni, S., LeMieux, M. C., Lang, H. P., Gerber, C., Lam, Y., Zauscher, S., et al. (2008). Bimaterial microcantilevers as a hybrid sensing platform. Adv. Mater. 20, 653-680. doi: 10.1002/adma.200701667

Stassi, S., Fantino, E., Calmo, R., Chiappone, A., Gillono, M., Scaiola, D., et al. (2017). Polymeric 3D printed functional microcantilevers for biosensing applications. ACS Appl. Mater. Interf. 9, 19193-19201. doi: 10.1021/acsami.7b04030

Stoney, G. G. (1909). The tension of metallic films deposited by electrolysis. Proc. R Soc. London A Math. Phys. Eng. Sci. 82, 172-175. doi: 10.1098/rspa.1909.0021 Stupar, P., Chomicki, W., Maillard, C., Mikeladze, D., Kalauzi, A., Radotić, K., et al. (2017a). Mitochondrial activity detected by cantilever based sensor. Mech. Sci. 8, 23-28. doi: 10.5194/ms-8-23-2017

Stupar, P., Opota, O., Longo, G., Prod'hom, G., Dietler, G., Greub, G., et al. (2017b). Nanomechanical sensor applied to blood culture pellets: a fast approach to determine the antibiotic susceptibility against agents of bloodstream infections. Clin. Microbiol. Infect. 23, 400-405. doi: 10.1016/j.cmi.2016.12.028 
Sungkanak, U., Sappat, A., Wisitsoraat, A., Promptmas, C., and Tuantranont, A. (2010). Ultrasensitive detection of Vibrio cholerae O1 using microcantileverbased biosensor with dynamic force microscopy. Biosens. Bioelectron. 26, 784-789. doi: 10.1016/j.bios.2010.06.024

Syal, K., Iriya, R., Yang, Y., Yu, H., Wang, S., Haydel, S. E., et al. (2016). Antimicrobial susceptibility test with plasmonic imaging and tracking of single bacterial motions on nanometer scale. ACS Nano 10, 845-852. doi: $10.1021 / a c s n a n o .5 b 05944$

Syal, K., Mo, M., Yu, H., Iriya, R., Jing, W., Guodong, S., et al. (2017a). Current and emerging techniques for antibiotic susceptibility tests. Theranostics 7 , 1795-1805. doi: 10.7150/thno.19217

Syal, K., Shen, S., Yang, Y., Wang, S., Haydel, S. E., and Tao, N. (2017b). Rapid antibiotic susceptibility testing of uropathogenic $E$. coli by tracking submicron scale motion of single bacterial cells. ACS Sens. 2, 1231-1239. doi: 10.1021/acssensors.7b00392

Tamayo, J., Kosaka, P. M., Ruz, J. J., Paulo, Á. S., and Calleja, M. (2013). Biosensors based on nanomechanical systems. Chem. Soc. Rev. 42, 1287-1311. doi: $10.1039 / \mathrm{C} 2 \mathrm{CS} 35293 \mathrm{~A}$

Tomkins, M. R., Chow, J., Lai, Y., and Docoslis, A. (2013). A coupled cantilevermicroelectrode biosensor for enhanced pathogen detection. Sens. Actuators $B$ Chem. 176, 248-252. doi: 10.1016/j.snb.2012.09.020

Tsouti, V., Boutopoulos, C., Zergioti, I., and Chatzandroulis, S. (2011). Capacitive microsystems for biological sensing. Biosens. Bioelectron. 27, 1-11. doi: $10.1016 /$ j.bios.2011.05.047

Tsouti, V., and Chatzandroulis, S. (2012). Sensitivity study of surface stress biosensors based on ultrathin Si membranes. Microelectron. Eng. 90, 29-32. doi: 10.1016/j.mee.2011.04.061

Tsouti, V., and Chatzandroulis, S. (2015). Non-ideal biological layer deposition effects on membrane surface stress based biosensor performance. Microelectron. Eng. 144, 23-26. doi: 10.1016/j.mee.2015.01.025

Urwyler, P., Schift, H., Gobrecht, J., Häfeli, O., Altana, M., Battiston, F., et al. (2011). Surface patterned polymer micro-cantilever arrays for sensing. Sens. Actuators A Phys. 172, 2-8. doi: 10.1016/j.sna.2010.12.007

Valdez, L. M., Dang, H., Okhuysen, P. C., and Chappell, C. L. (1997). Flow cytometric detection of Cryptosporidium oocysts in human stool samples. J. Clin. Microbiol. 35, 2013-2017. doi: 10.1128/JCM.35.8.2013-2017.1997

Valones, M. A. A., Guimarães, R. L., Brandão, L. A. C., Souza, P. R. E., de, Carvalho, A., de, A. T., et al. (2009). Principles and applications of polymerase chain reaction in medical diagnostic fields: a review. Braz. J. Microbiol. 40, 1-11. doi: $10.1590 /$ S1517-83822009000100001

Verd, J., Uranga, A., Abadal, G., Teva, J. L., Torres, F., LÓpez, J., et al. (2008). Monolithic CMOS MEMS oscillator circuit for sensing in the attogram range. IEEE Electron. Device Lett. 29, 146-148. doi: 10.1109/LED.2007.914085

Villalba, M. I., Stupar, P., Chomicki, W., Bertacchi, M., Dietler, G., Arnal, L., et al. (2018). Nanomotion detection method for testing antibiotic resistance and susceptibility of slow-growing bacteria. Small 14:1702671. doi: $10.1002 /$ smll.201702671
Waggoner, P. S., and Craighead, H. G. (2007). Micro- and nanomechanical sensors for environmental, chemical, and biological detection. Lab. Chip 7, 1238-1255. doi: $10.1039 / \mathrm{b} 707401 \mathrm{~h}$

Wang, J., Morton, M. J., Elliott, C. T., Karoonuthaisiri, N., Segatori, L., and Biswal, S. L. (2014). Rapid detection of pathogenic bacteria and screening of phage-derived peptides using microcantilevers. Anal. Chem. 86, 1671-1678. doi: $10.1021 /$ ac403437x

Weeks, B. L., Camarero, J., Noy, A., Miller, A. E., De Yoreo, J. J., and Stanker, L. (2006). A microcantilever-based pathogen detector. Scanning 25, 297-299. doi: $10.1002 /$ sca. 4950250605

Wu, S., Liu, X., Zhou, X., Liang, X. M., Gao, D., Liu, H., et al. (2016). Quantification of cell viability and rapid screening anti-cancer drug utilizing nanomechanical fluctuation. Biosens. Bioelectron. 77, 164-173. doi: 10.1016/j.bios.201 5.09 .024

Yen, Y.-K., and Chiu, C.-Y. (2020). A CMOS MEMS-based membrane-bridge nanomechanical sensor for small molecule detection. Sci. Rep. 10:2931. doi: 10.1038/s41598-020-60057-8

Yi, J. W., Shih, W. Y., Mutharasan, R., and Shih, W.-H. (2003). In situ cell detection using piezoelectric lead zirconate titanatestainless steel cantilevers. J. Appl. Phys. 93, 619-625. doi: 10.1063/1.1 524022

Yoon, Y., Chae, I., Thundat, T., and Lee, J. (2019). Hydrogel microelectromechanical system (MEMS) resonators: beyond cost-effective sensing platform. Adv. Mater. Technol. 4:1800597. doi: $10.1002 /$ admt.201800597

Yoshikawa, G., Akiyama, T., Gautsch, S., Vettiger, P., and Rohrer, H. (2011). Nanomechanical membrane-type Surface Stress Sensor. Nano Lett. 11, 1044-1048. doi: 10.1021/nl103901a

Zhang, J., and Ji, H.-F. (2004). An anti E. Coli O157:H7 antibody-immobilized microcantilever for the detection of Escherichia Coli (E. coli). Anal. Sci. 20, 585-587. doi: 10.2116/analsci.20.585

Zheng, F., Wang, P., Du, Q., Chen, Y., and Liu, N. (2019). Simultaneous and ultrasensitive detection of foodborne bacteria by gold nanoparticlesamplified microcantilever array biosensor. Front. Chem. 7:232 doi: $10.3389 /$ fchem.2019.00232

Conflict of Interest: The authors declare that the research was conducted in the absence of any commercial or financial relationships that could be construed as a potential conflict of interest.

Copyright (ㄷ) 2020 Pujol-Vila, Villa and Alvarez. This is an open-access article distributed under the terms of the Creative Commons Attribution License (CC BY). The use, distribution or reproduction in other forums is permitted, provided the original author(s) and the copyright owner(s) are credited and that the original publication in this journal is cited, in accordance with accepted academic practice. No use, distribution or reproduction is permitted which does not comply with these terms. 